\title{
المحرمات من الأطعمة الواردة في القرآن الكريم وعلاقتها بالأوبئة دراسة موضوعية
}

\author{
Forbidden Foods in the Holy Qur'an and their Relationship with \\ Pandemics: A Thematic Study
}

\section{Makanan Yang Diharamkan Untuk Umat Islam Dimakan Menurut Al-Quran dan Hubungannya Dengan Pandemik: Kajian Objektif}

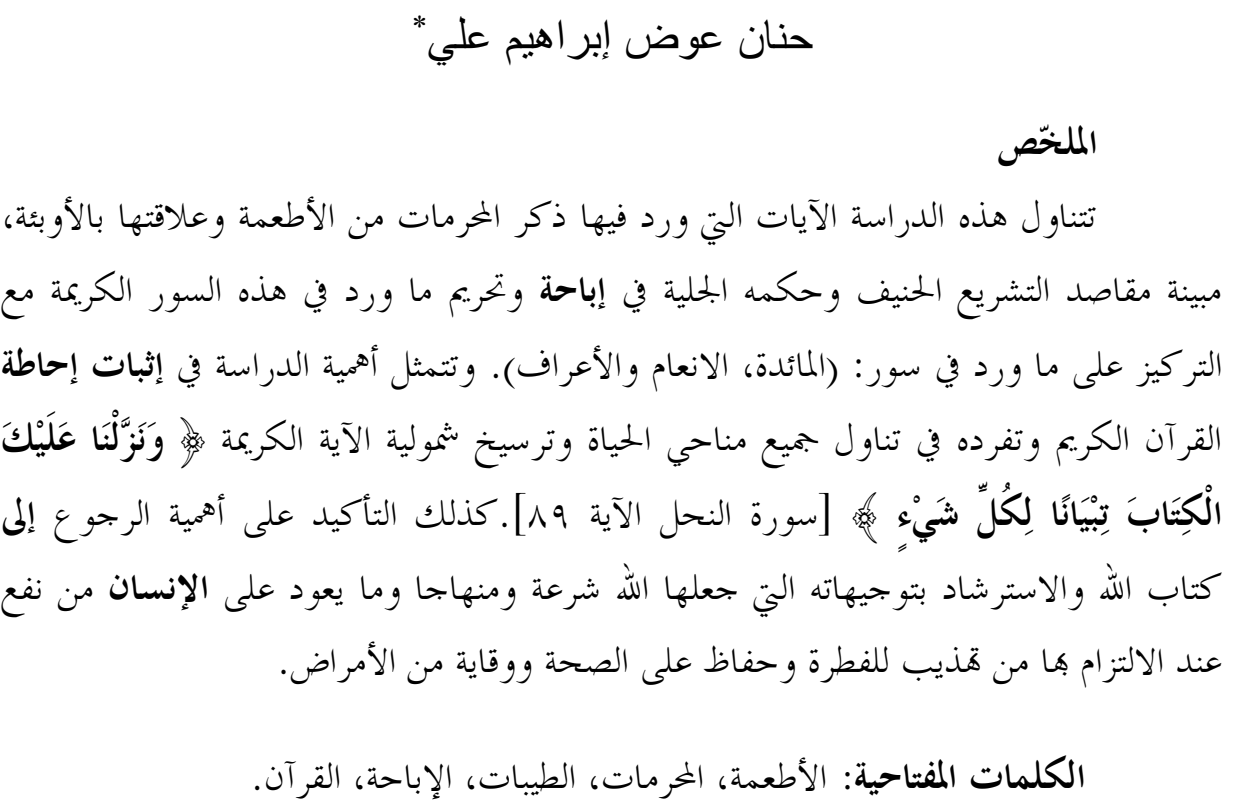

\section{Abstract}

This study deals with what foods are allowed and not allowed for Muslims to eat according to the Holy Quran. This study also shows why these foods are banned and how these foods are closely related to pandemics. This wisely proves How conclusive the Holy Quran is! The verses which support this idea are included in the Surahs such as (Al-Ma'dah, Al-An'am, and Al-Araf). The search signifies that the Holy Quran includes uniquely all walks of human life. For example, At Surah Al-Ana'm verse 89, Allah says, (......and WE have sent down to you (prophet Muhammad) PBUH, the Quran as exposition of everything, a guidance, a mercy and glad tidings for those

$$
\begin{aligned}
& \text { * أستاذ مساعد بقسم الدراسات الإسلامية، كلية الآداب، جامعة الإمام عبد الرحمن بن فيصل، البريد الإلكتروي: } \\
& \text { haiali@iau.edu.sa }
\end{aligned}
$$

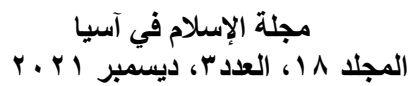

$$
\begin{aligned}
& \text { الجامعة الإسلامية العالمية الماليزية }
\end{aligned}
$$

E-ISSN: 2289-8077

DOI: https://doi.org/10.31436/jia.v18i3.1044 


$$
\text { الخرمات من الأطعمة الواردة في القر آن الكريم وعلاقتها بالأوبئة }
$$

who have submitted themselves to Allah). This verse goes side by side with the straight human nature and it is a real application to the English wise saying, (prevention is better than cure).To sum up, the Holy Quran has an amazing impact on humans as it protects them from pandemics.

Keywords: Foods, Forbidden, Al-Tayibat, Permissibility, Qur'an.

\section{Abstrak}

Kajian ini membincangkan makanan yang dibenarkan dan tidak dibenarkan untuk dimakan oleh orang Islam mengikut Perlembagaan Al-Quran. Kajian ini juga menunjukkan mengapa makanan ini diharamkan dan bagaimana makanan ini berkait rapat dengan Pandemik. Ini dengan bijak membuktikan betapa konklusifnya AlQuran!!!! Ayat-ayat yang menyokong idea ini termasuk dalam Surah-surah seperti (AlMa'dah, Al-An'am, dan Al-Araf). Pencarian menandakan bahawa Al-Quran merangkumi unik semua lapisan kehidupan manusia. Sebagai contoh, dalam Surah AlAna'm ayat 89, Allah berfirman, (.....dan KAMI turunkan kepadamu (Nabi Muhammad) s.a.w., Al-Quran untuk menjelaskan segala sesuatu, petunjuk, rahmat dan khabar gembira. bagi mereka yang berserah diri kepada Allah). Ayat ini berdampingan dengan sifat manusia yang lurus dan ia adalah aplikasi sebenar kepada pepatah bijak Inggeris, (mencegah lebih baik daripada mengubati). Kesimpulannya, Al-Quran mempunyai kesan yang menakjubkan kepada manusia kerana ia melindungi mereka daripada Pandemik.

Kata Kunci: Makanan, Haram, Al-Tayibat, Kebolehan, Al-Quran.

$$
\begin{aligned}
& \text { المقدمة } \\
& \text { الحمد لله رب العالمين، و الصلاة والسلام على سيد المرسلين محمد بن عبد } \\
& \text { الله، وعلى آله وصحبه أجمعين، وبعد: } \\
& \text { فإنَّ هذا البحث يتحدث عن الأطعمة المحللة والمرمة وعلاقتها بالأوبئة } \\
& \text { كدراسة تطبيقية في بعض آيات الأحكام الواردة سور: (المائدة، الأنعام والأعراف). } \\
& \text { وقد انصب هذا البحث على دراسة المنظور القرآني لأحكام الأطعمة من خلال ما } \\
& \text { ورد في السور. } \\
& \text { فقد حث الإسلام على الأكل الحلال، وحذَّر مِن الأكل من الحرام، قال }
\end{aligned}
$$

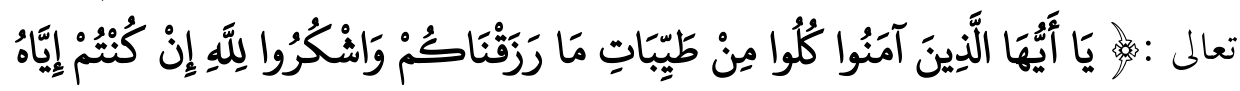




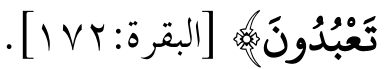

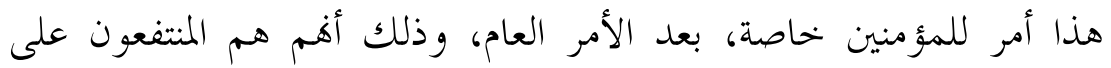

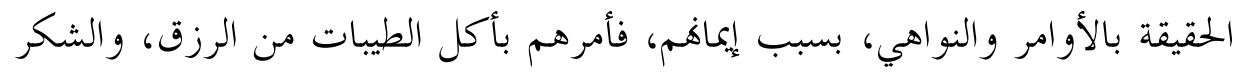

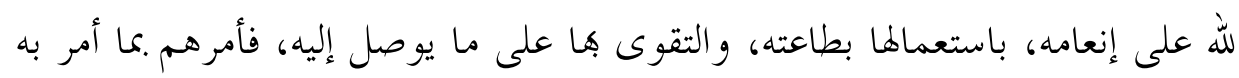

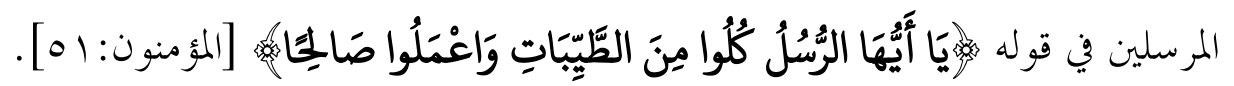

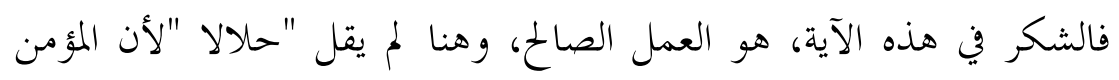

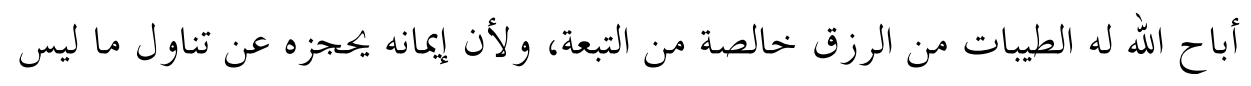

وقد نظمت الشريعة الإسلامية للإنسان حياته العامة والخاصة تنظيماً دقيقاً،

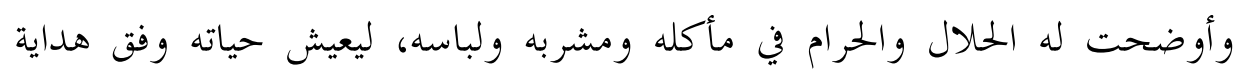

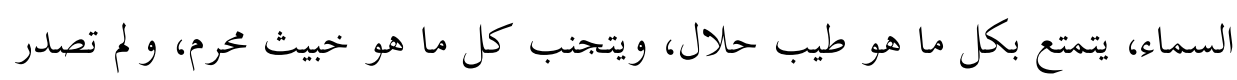

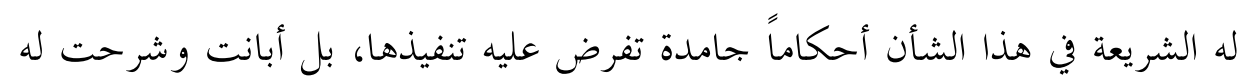
فلسفة تحليل الطيبات وتحريم الحبائث ليقبل على أحكامها قانعاً مختارا.

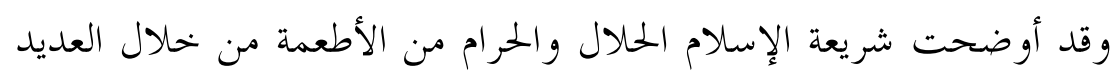

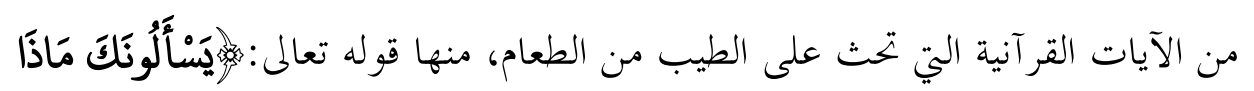

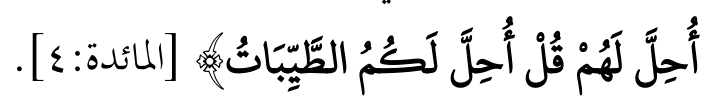

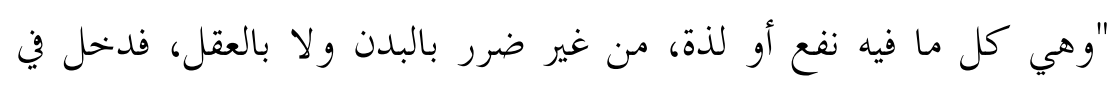

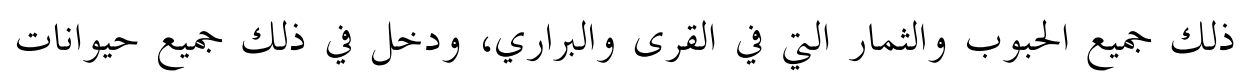

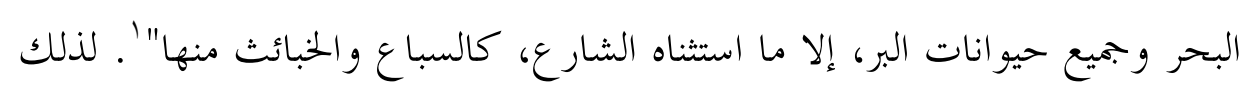

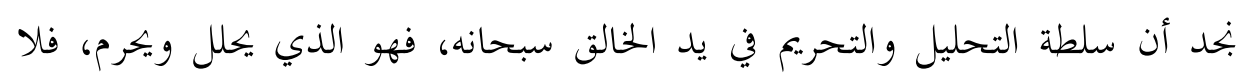

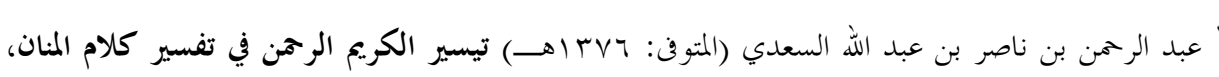

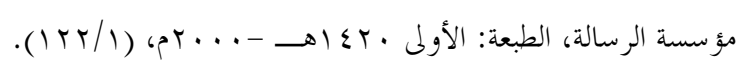




$$
\text { الخرمات من الأطعمة الواردة في القر آن الكريم وعلاقتها بالأوبئة }
$$

وصاية لأحد مهما كان علمه وفكره وقدراته العقلية على شرع الله، والذي يحلل

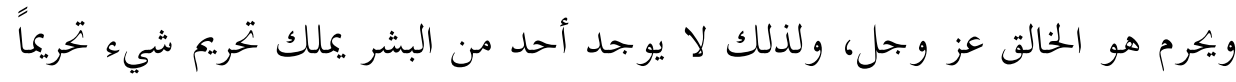

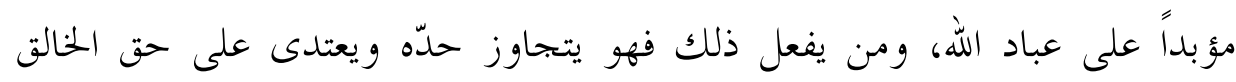

$$
\text { ويستحق العقاب واللعنة. }
$$

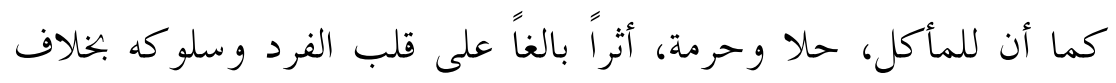

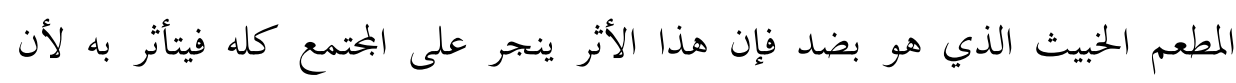

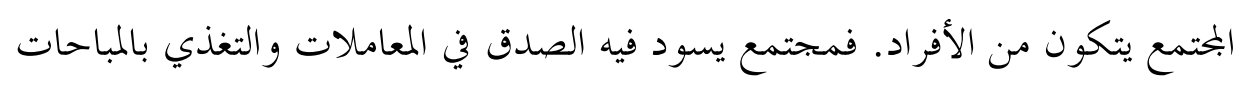

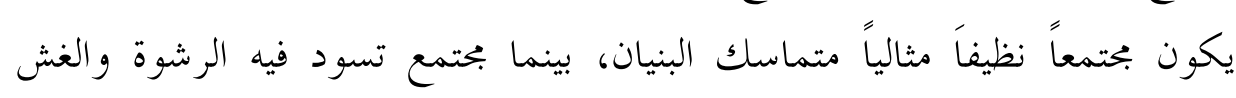
والتغذي بالخرمات يكون بحتمعاً ملوثا.

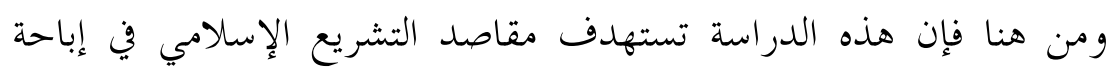

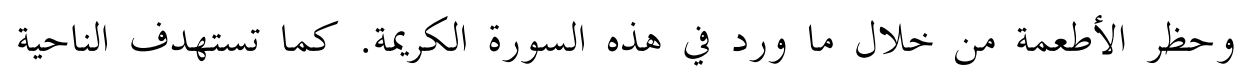

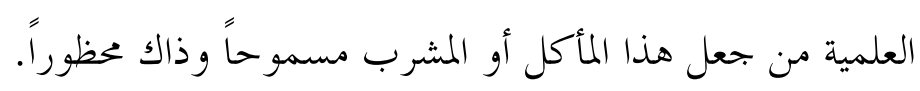

\section{تكمن أهمية الموضوع وأسباب اختياره في الخحاور التالية:}

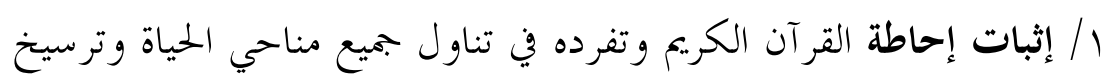

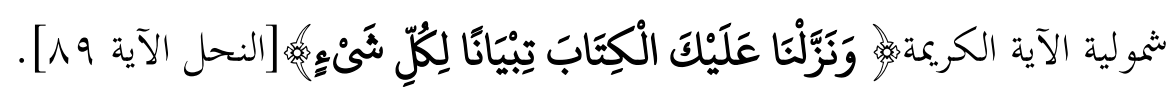

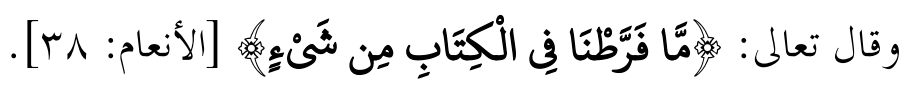

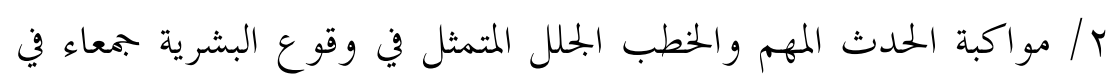

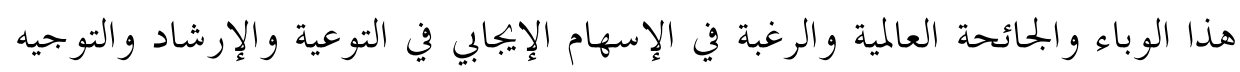
من الناحية الشرعية بالنهل من معين القرآن الكريع.

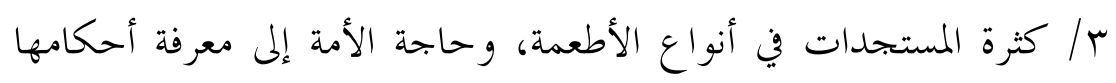

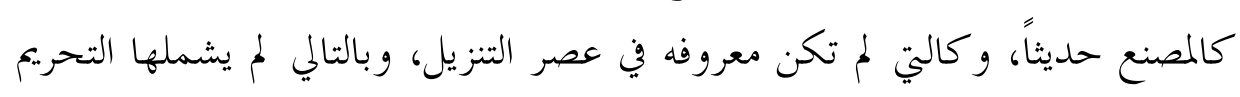




$$
\text { ولكنها لا تزال محل شبهة. }
$$

ع / أثبتت التجسارب المعملية علاقة لحم الخنزير بعدد من الفايروسات.

$$
\text { وعلى سبيل المثال: }
$$

أو الذي انتشر في ماليزيا عام 1991 وأثبت (Nipah Virus): أنايروس نيات

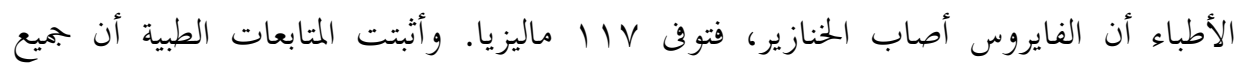

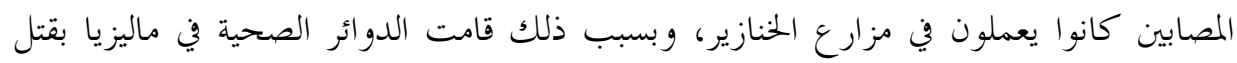
مليون خنز ير.

ثانيا: بكتيريا السلمونيا : (salmonellosis) التيفوئيد، وبارا التيفوئيد، والتسمم

$$
\text { الغذائي، من الأمراض التي تسببها السلمونيا. }
$$

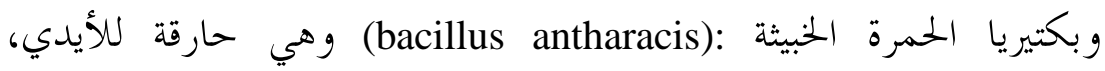
يصاحبها ارتفاع في درجات الحرارة، والتهاب الأوعية اللمفاوية. وهذا يثبت التطابق بين دين الإسلام والحقائق العلمية الحديثة.

$$
\begin{aligned}
& \text { ويهدف البحث إلى: } \\
& \text { 1. التأكيد على أهمية الرجوع المى كتاب الله والاسترشاد بتوجيهاته التي }
\end{aligned}
$$

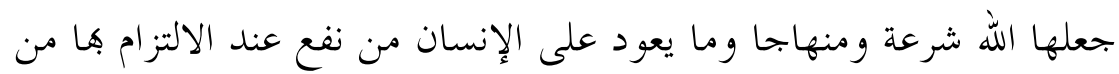

$$
\begin{aligned}
& \text { هذيب للفطرة وحفاظ على الصحة ووقاية من الأمراض. }
\end{aligned}
$$

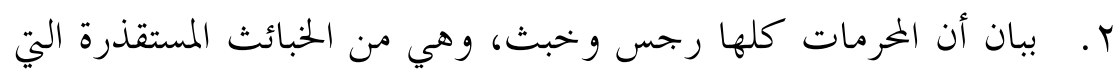

$$
\begin{aligned}
& \text { حرمها الله على عباده. }
\end{aligned}
$$

r. الإشارة فيما أمرت به الشريعة الإسلامية في بيان المرمات من الأطعمة

$$
\text { التي حرمها الله على عباده. }
$$

ـ. إثبات أن تحريم الإسلام لبعض عباده الأطعمة إنما هو حماية لصحة الإنسان من 


\section{منهج البحث}

تقتضي طبيعة البحث استخدام المنهج التكاملي المشتمل على عدد من المناهج

البحثية منها المنهج الاستقرائي والتحليلي والاستدلالي: الذي يقوم على الاستقراء من خلال ما ورد في القرآن الكريم. و السنة النبوية وأقو ال السلف والأئمة ...

\section{المبحث الأول: المباح من الأطعمة}

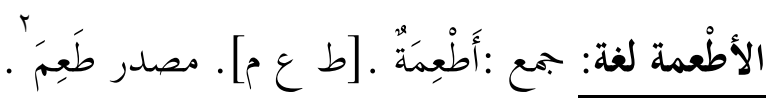

r

وقال جماعة من أهل اللغة: الطعام يقع على كل ما يطعم حتى الماء.

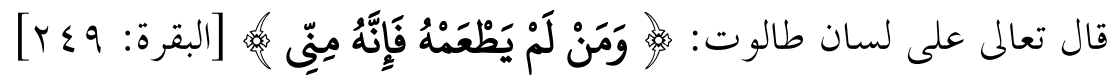

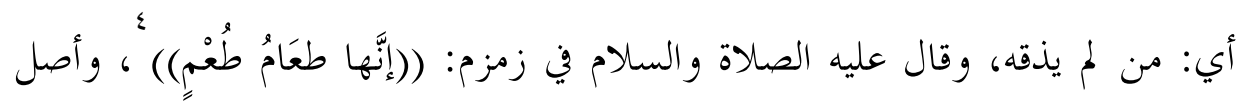
(طعم): يدل على تذوقِ الشَّيَِّ .

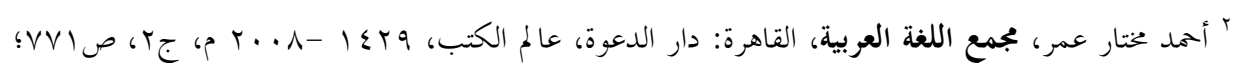

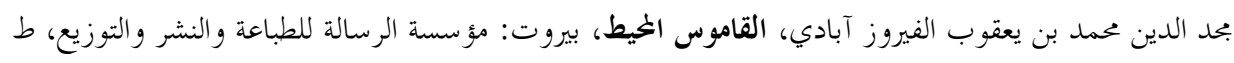
A

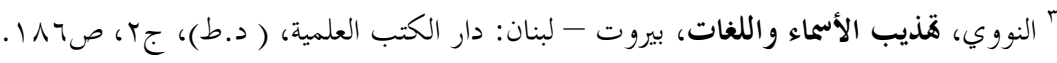

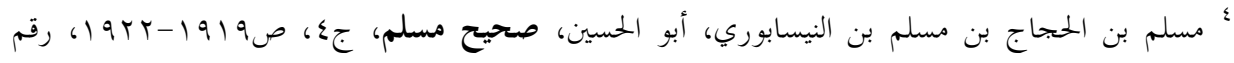

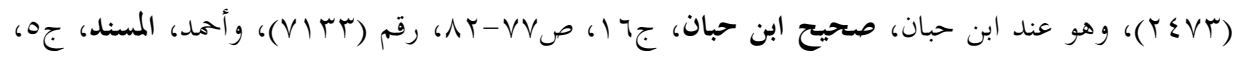

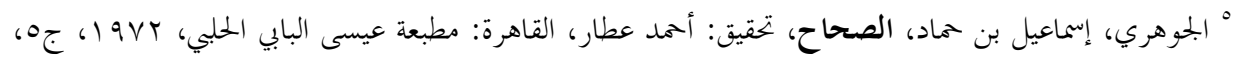

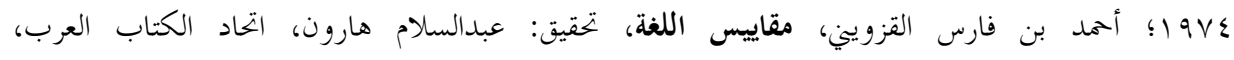


الأطُعمة اصطِلاحًا: ما يحل وما حرم من المأكول والمَشروبَ .

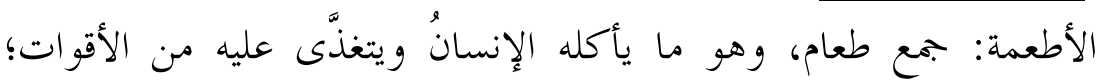

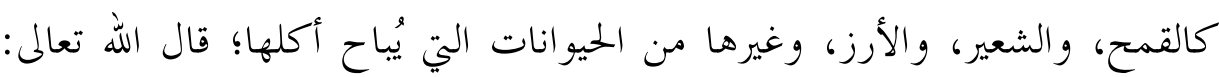

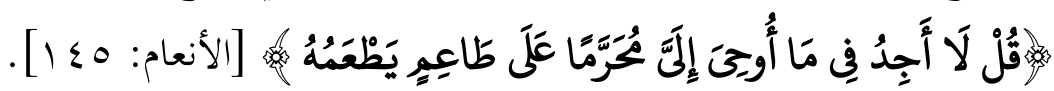

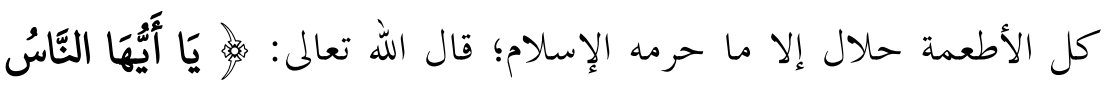

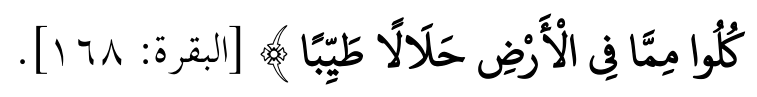

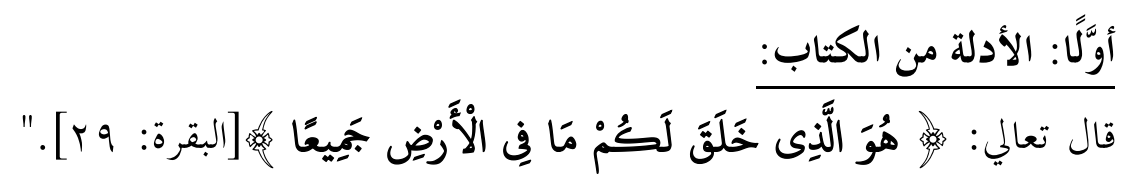

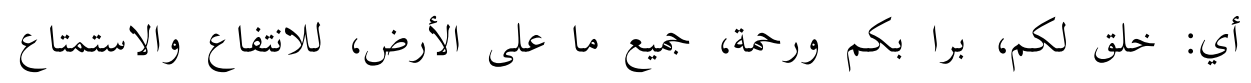
والاعتبار.

وفي هذه الآية الكريمة ' دليل على أن الأصل في الأشياء الإباحة والطهارة،

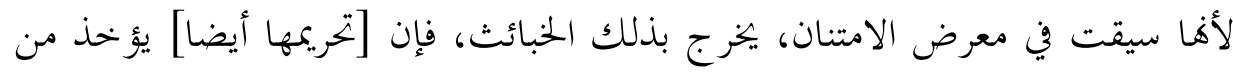

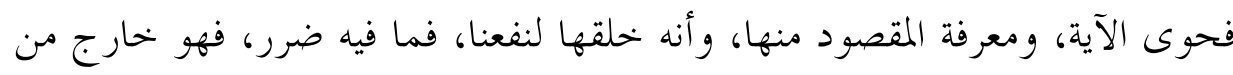
$\wedge$ ذلك، ومن تمام نعمته، منعنا من الخبائث، تنز يها لنا .

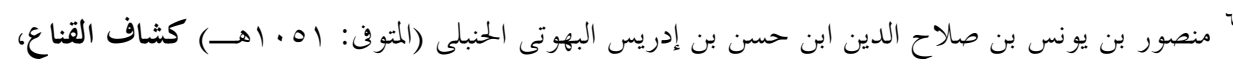

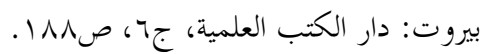

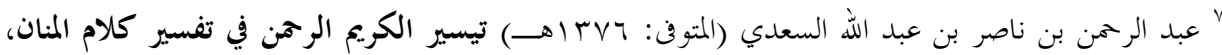

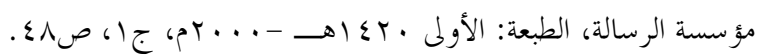

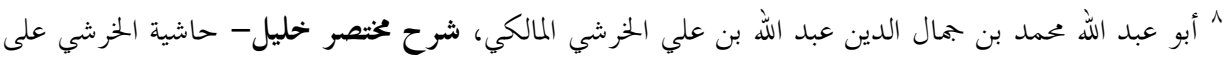

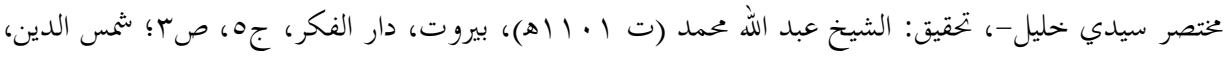

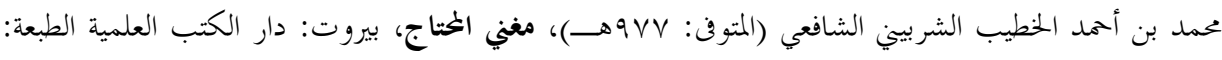

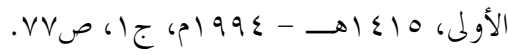




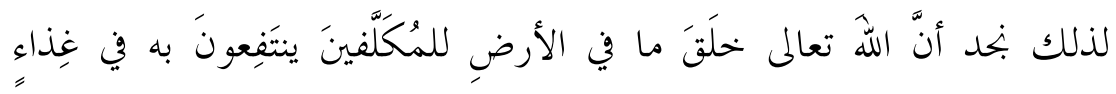

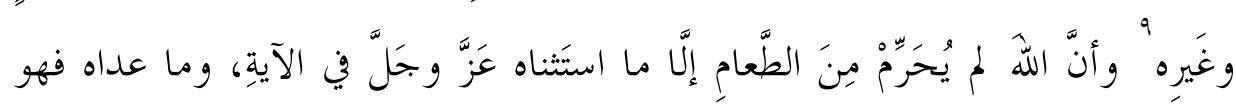
حَلاله.

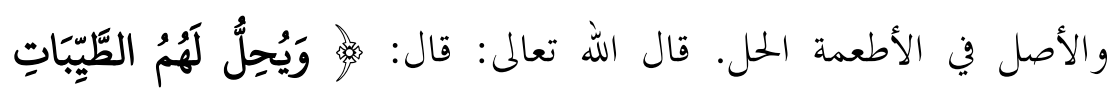

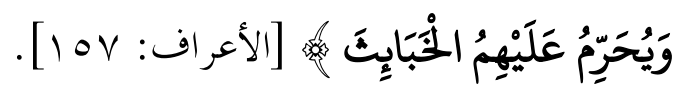

قال القرطبي: "وقوله:

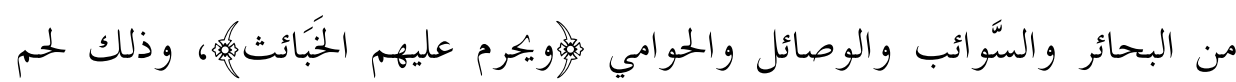

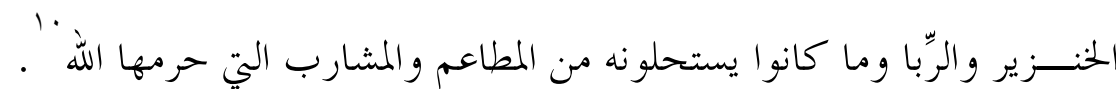

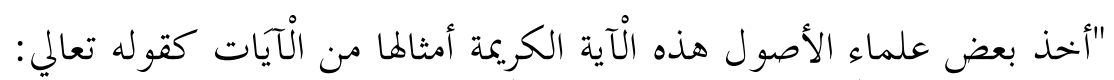

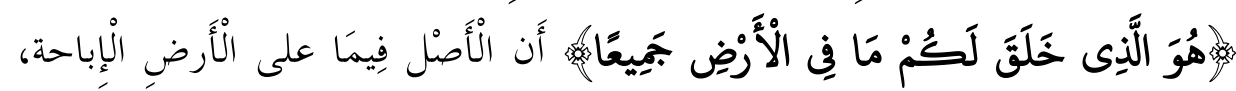

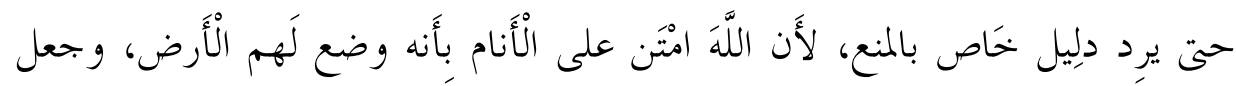

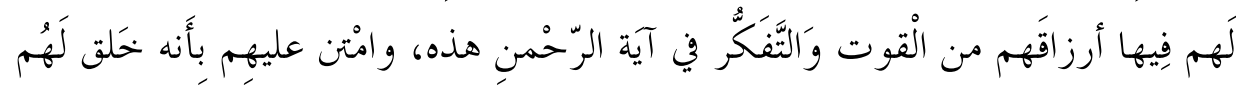

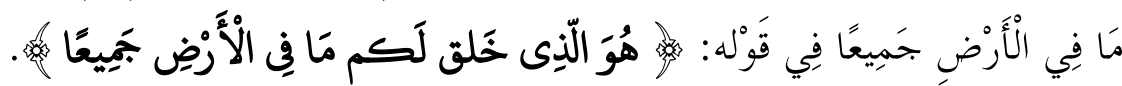

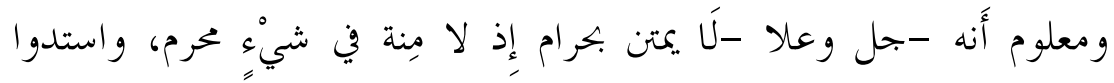

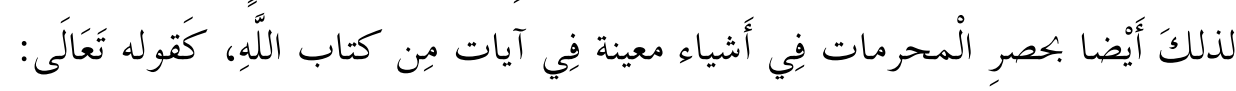

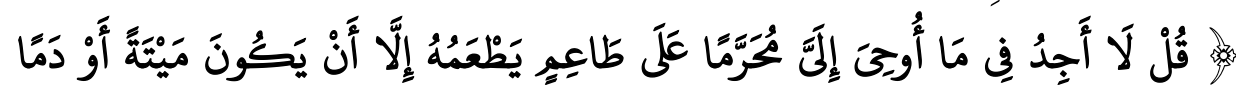

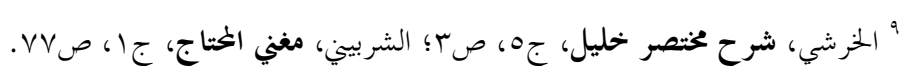

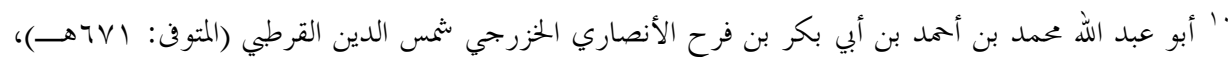

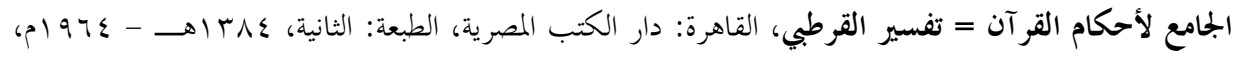

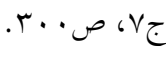


ثنانيًا: الادلة من السنة:

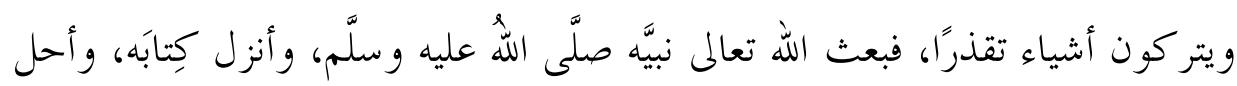

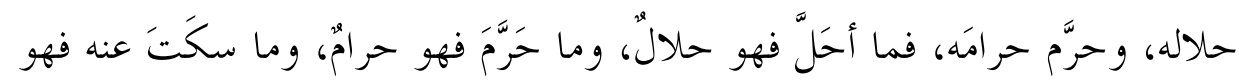

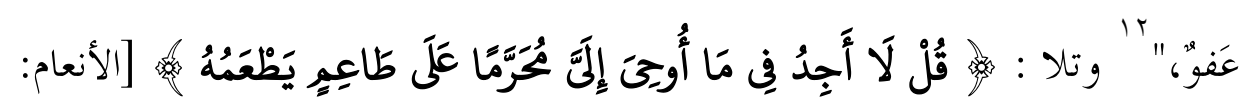
. [10

هذا نص في ما سكت عنه فلا إثم عليه فيه، وتسمية هذا عَفوًا؛ لأن التحليل

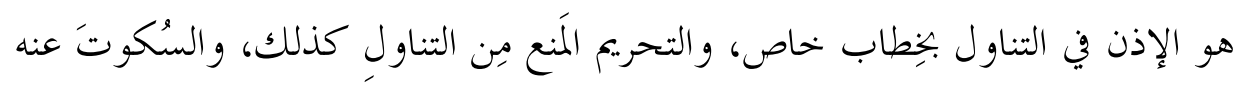

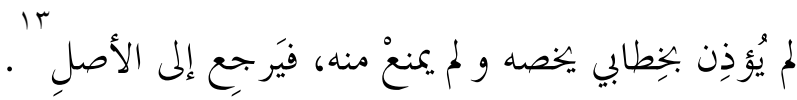

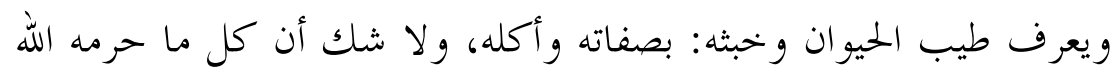
عز وجل أو نص على خُبثه فهو خبيث ضارٌ في البدن والدين.

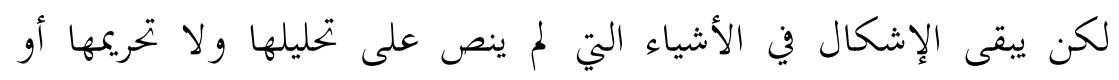

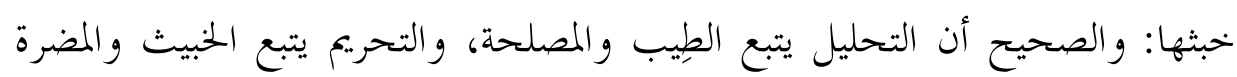

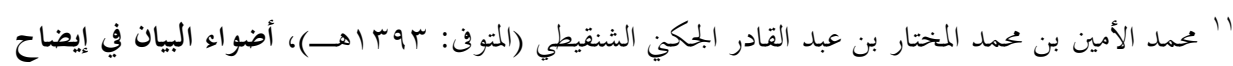

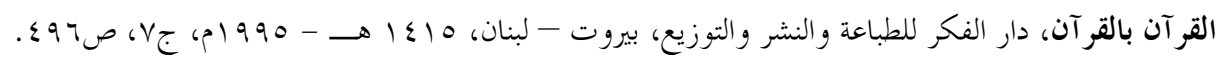

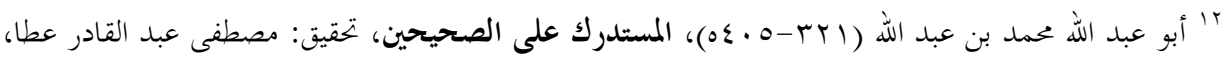

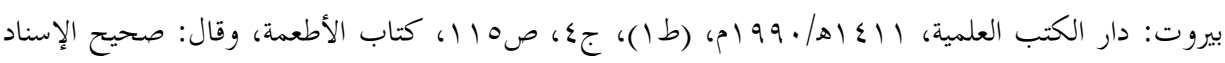

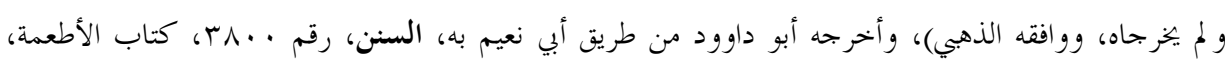

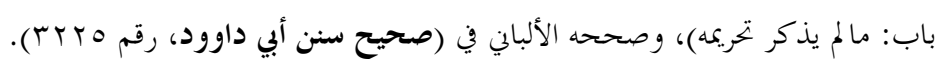

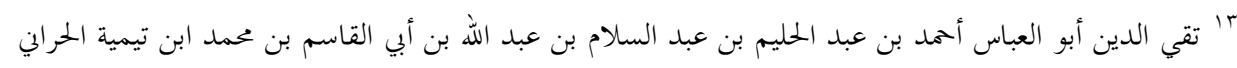

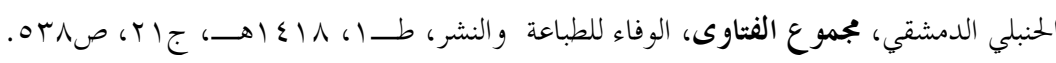


في ذات الأشياء لا في اعتبار الناس؛ لأن الناس قد يتلذذون بما يضرهم من السموم

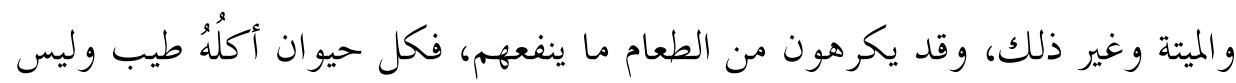

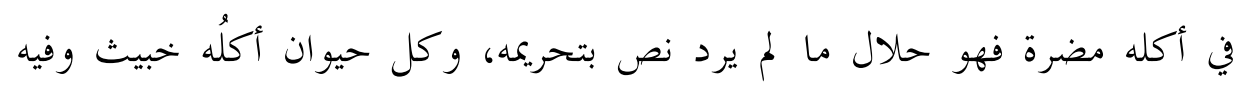

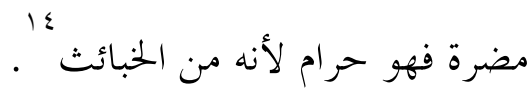

قال تعالى:

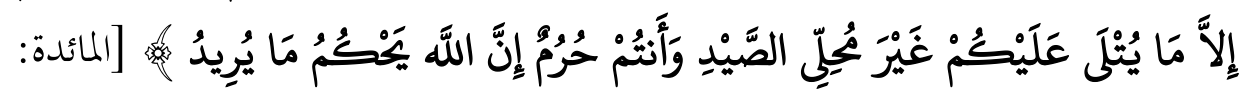

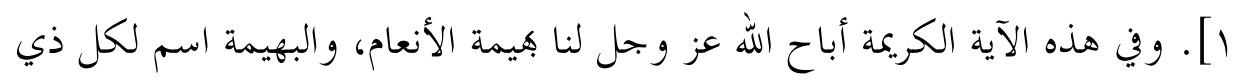
أربع، سميت بذلك لإبهامها من جهة نقص نطقها وفهمها وعقلها، ومنه باب مبهم

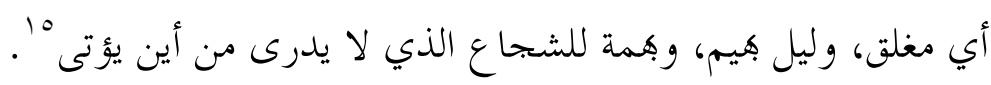

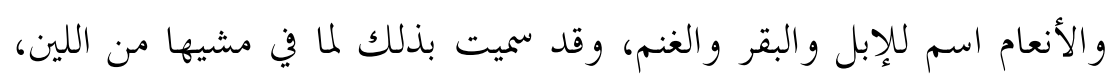

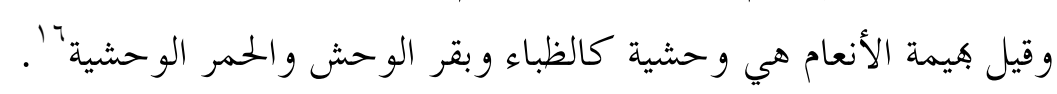
وقد ورد خحلاف في تحديد المقصود من هيمة الأنعام؛ فقال السدي والربيع والضحاك: إنه يشمل كل الأنعام، وقال ابن عباس والحسن: إنه يختص بالإبل و البقر

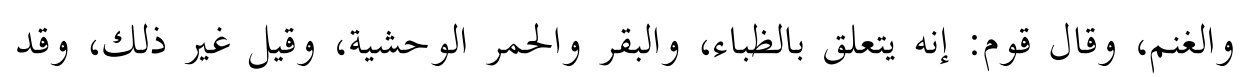

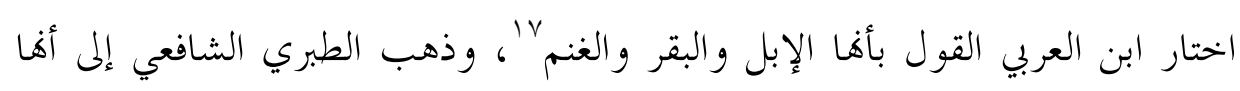

'ا إبراهيم بن عبد الله المزروعي، أحكام الحيوانات، ما يجوز أكله، وما لا يجوز، قسم الفقه، مقال تاريخ الإضافة:

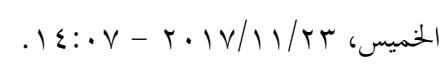

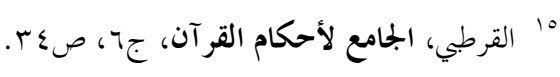

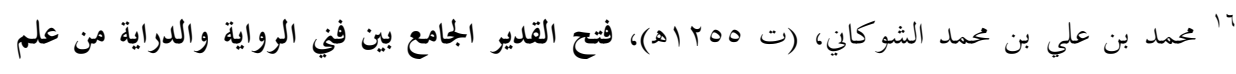

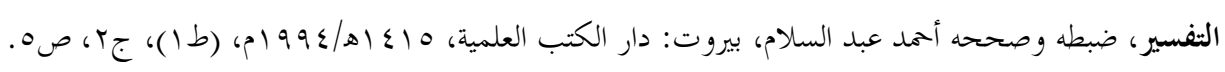

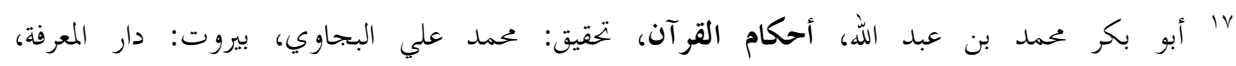


11

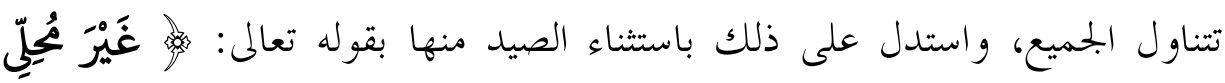

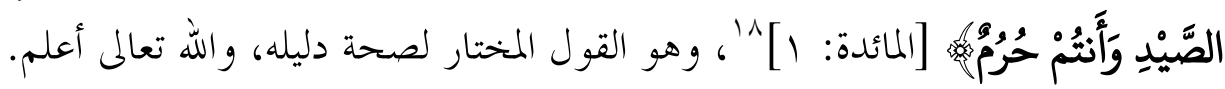

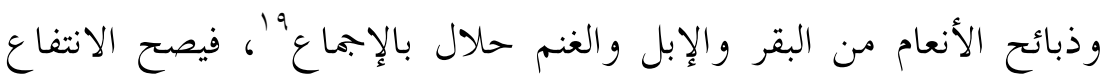

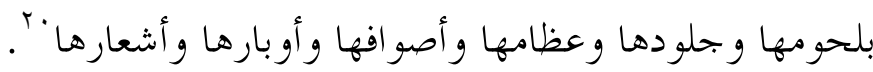
وانطلاقا مما سبق يتبين في الحقيقة الأهمية البالغة التي خصصتها الشريعة الإسلامية سواء وصل العلم البشري إلى حكمة هذا التحريم، أم لم يصل، فقد قرر العلم الإلهي أن هذه المطاعم ليست طيبة، وهذا وحده يكفي، فالله لا يُحرِّم إلا الحبائث، وإلا ما يؤذي الحياة البشرية في جانب من جوانبها؛ سواء علِم الناس هذا

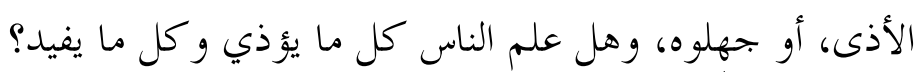

\section{المبحث الثالي: الخرمات من الأطعمة

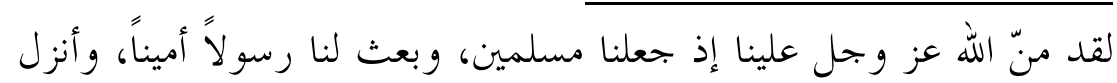 \\ علينا كتاباً عظيماً، وشرع لنا شرائع كثيرة، فأحل لنا الطيبات وحرم علينا الحنبائث ليخرجنا من الظلمات إلى النور بإذنه تعالى إنه هو الكريم الحليم، وهذه الآيات التي

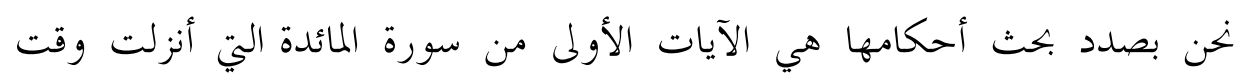

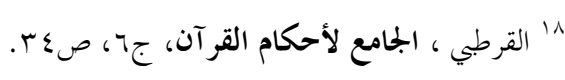

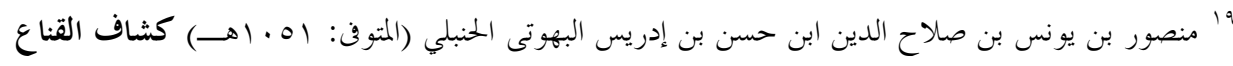

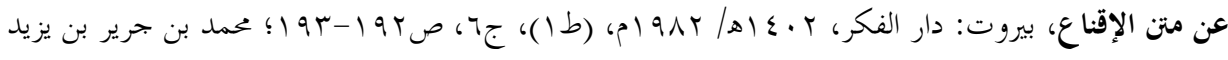

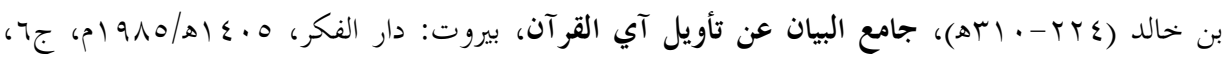

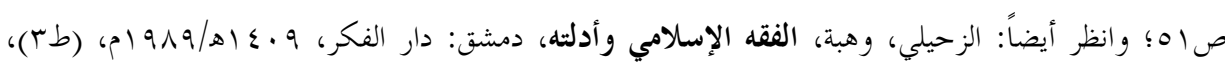


انصراف رسول الله صلى الله عليه وسلم من الحديبية، وهي سورة مدنية بالإجماع بَ،

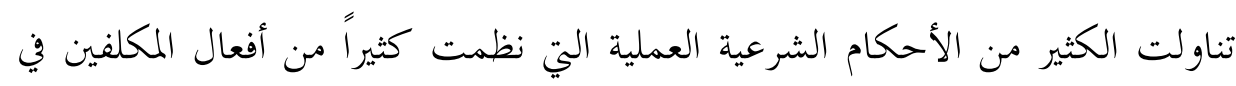
مختلف الموضوعات.

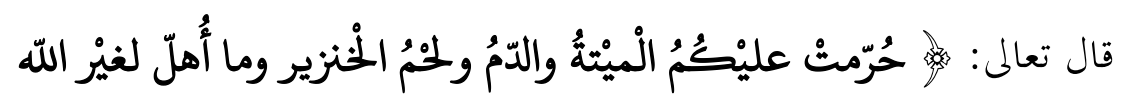

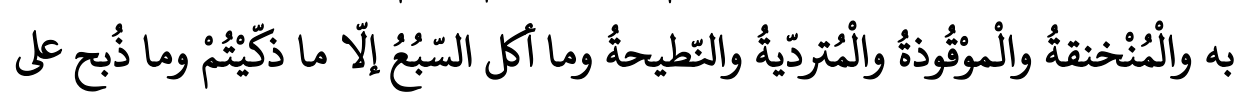

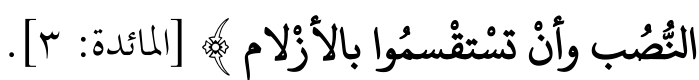
و سبب نزول هذه الآية كما ورد في الروايات عن حيان جال قال: "كنا مع رسول الله صلى الله عليه وسلم وأنا أوقد تحت قدر فيها لحم ميتة فأنزل الله [حكم]

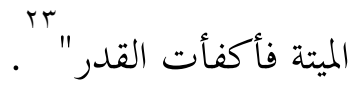
احتوت الآية الثالثة من سورة المائدة أحكاماً شرعية كثيرة تتعلق بعدة موضوعات، أهمها تحريم بعض الأطعمة وإباحة المظظورات من الأطعمة في حالة الضرورة. وقد ذكرت هذه الآية الكريمة بنصها جملة من الأمور المحرمة، والذي

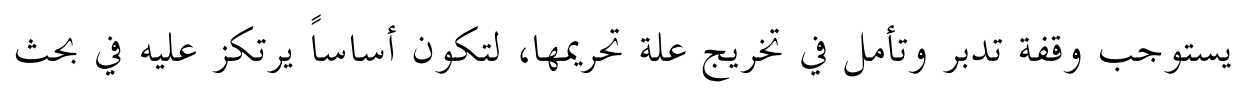
أحكام الأطعمة.

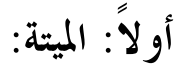

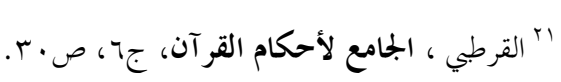

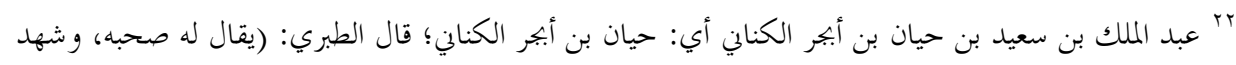

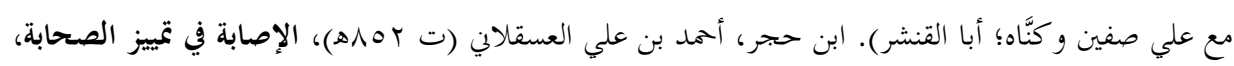

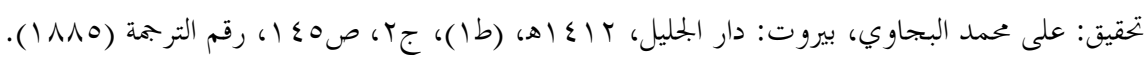

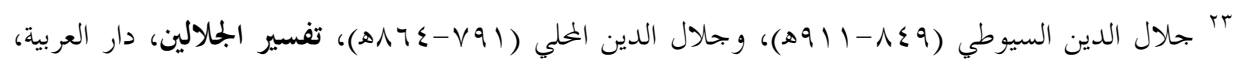


هي الحيو ان الذي يموت حتف أنفه ع وقيل هو ما قتل على هيئة غير مشروعة

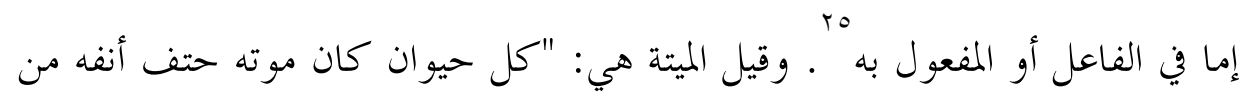
علة به غير جناية أحد عليه أو كان موته من ضرب ضارب إياه أو انخناق منه أو

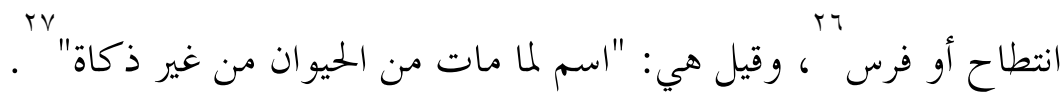

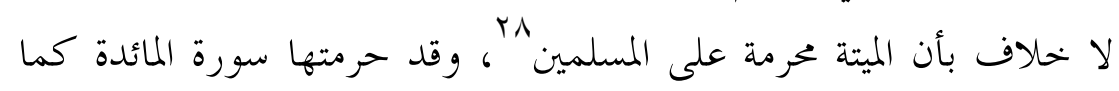

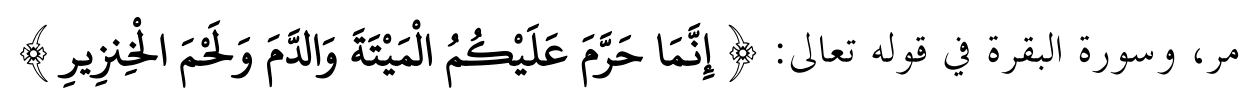

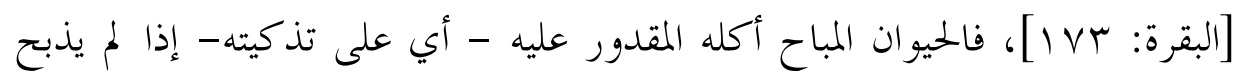
ذبحاً شرعياً فإنَّهُ يحرم بالإجماع و و ويعتبر ميتة. وأما إذا ثبت عدمُ ذبح الحيوانات على الطريقة الإسلامية، وأن وفاة هذه

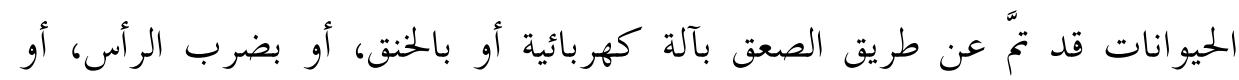

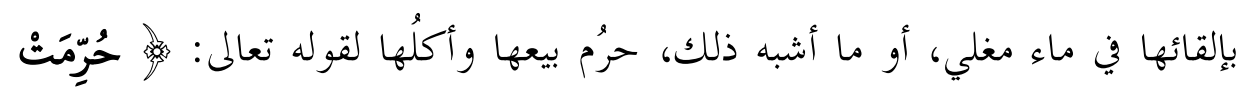

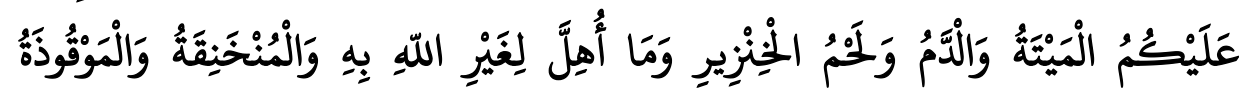

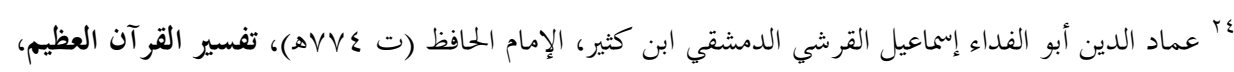

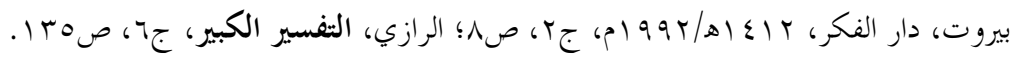

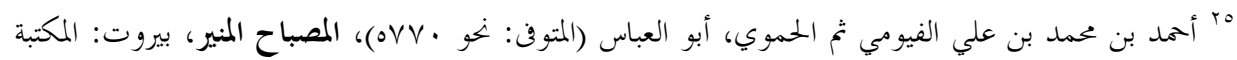
العلمية، صبr Tr.

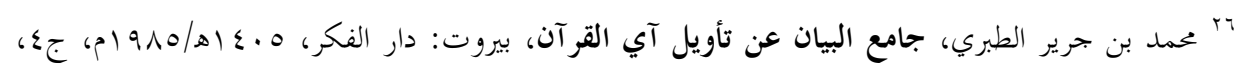
صד.

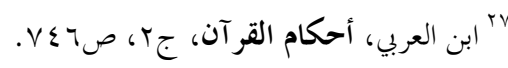

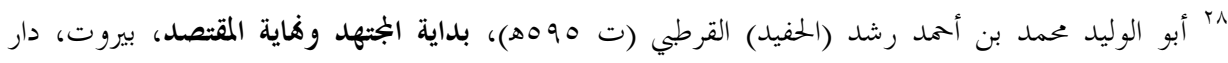

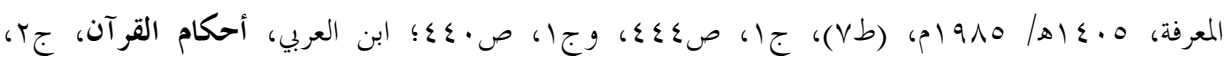
صז وُ برهان الدين علي بن أبي بكر شيخ الإسلام (ت بوهoه) المرغيناني، الهداية شرح بداية المبتدي، المكتبة

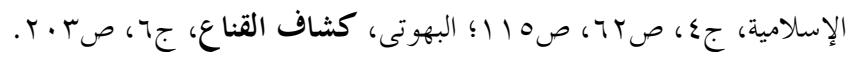




$$
\begin{aligned}
& \text { الخرمات من الأطعمة الواردة في القر آن الكريع وعلاقتها بالأوبئة }
\end{aligned}
$$

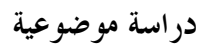

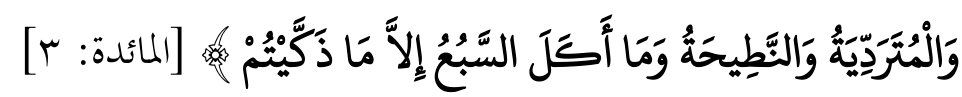

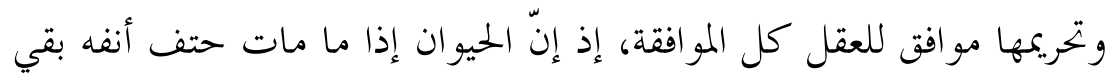

$r$.

دمه في عروقه وتعفن وفسد، فيحصل من أكله في هذه الحالة مضار عظيمة '.

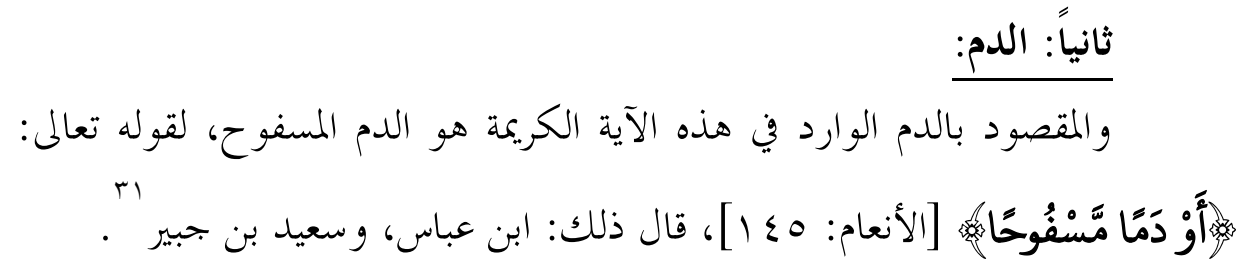

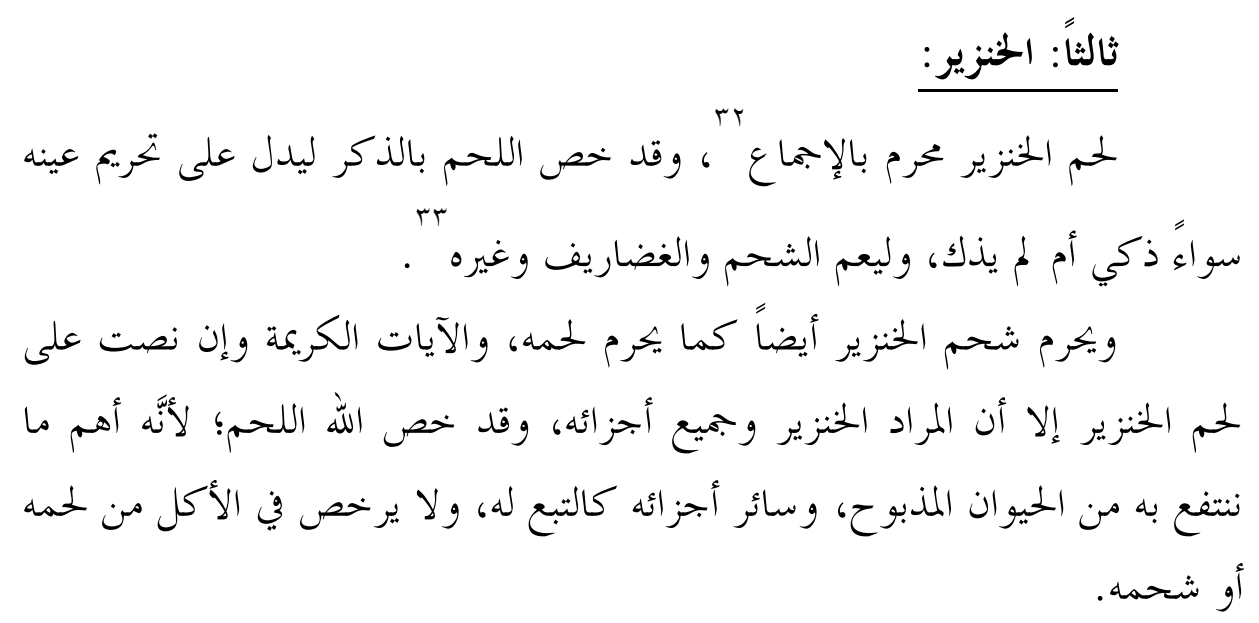

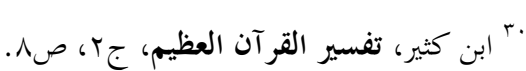

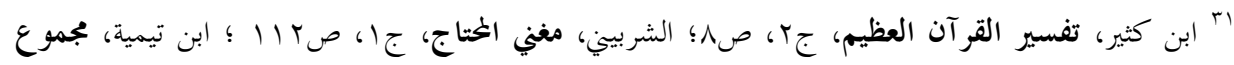

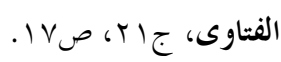

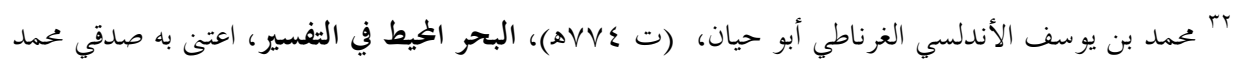

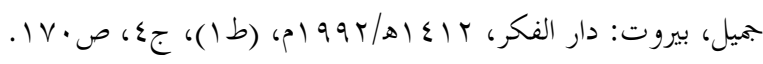

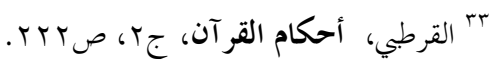


فِي الصحيحين: أَن رسول الله صلى اللَّه عَيه وَسلمَ قَالَ: "إن الله ورسوله حرم بيع الخمر والميتة والحنزير والأصنام"، فقيل: يا رسول الله، أرأيت شحوم الميتة،

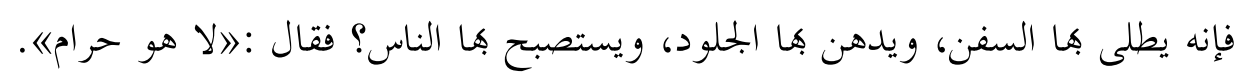

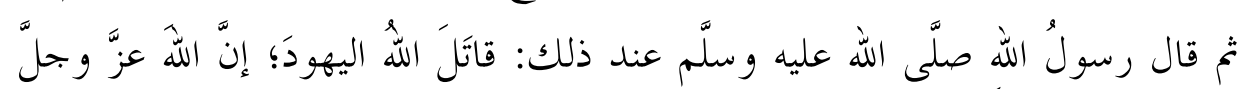

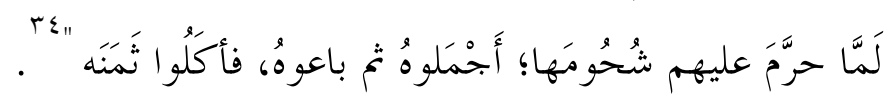
وفى هذا الحديث دليل على أجماع علماء الأمة الإسلامية من عهد البي -

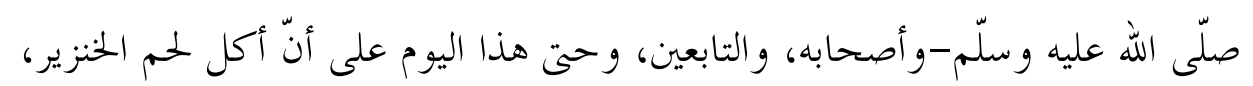

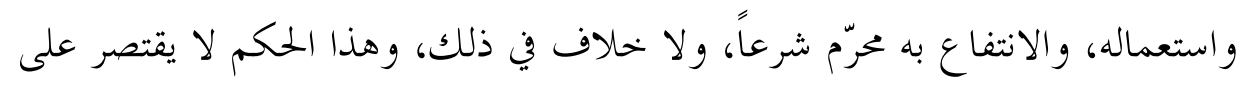

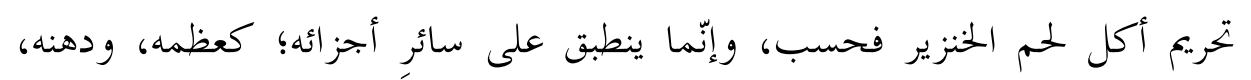
وطحاله، ودمه، ويشمل كذلك بيعه، وشراؤه، و واستغلاله بأيّ طريقةٍ كان.

\section{رابعاً: ما أهل لغير الله به والمنخنقة والموقوذة والمتردية والنطيحة وما أكل

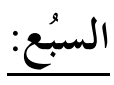 (أ) ما أهل لغير الله بله: (أله}

ويقصد به ما رفع الصوت به لغير الله تعالى عند ذبحه، والمراد بالإهلال ما لما لها لها

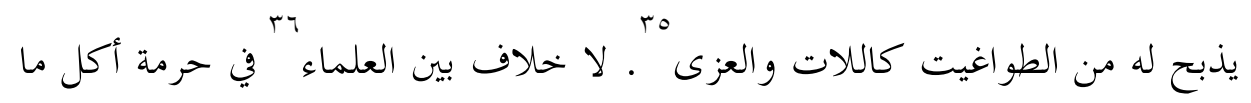

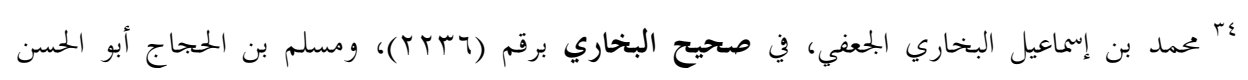

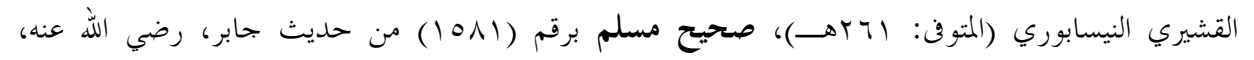
بيروت: دار إحياء التراث العربي.

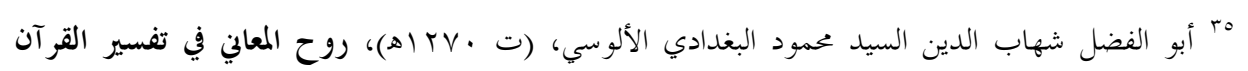

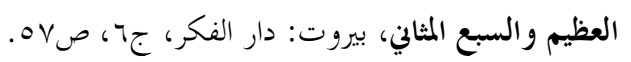

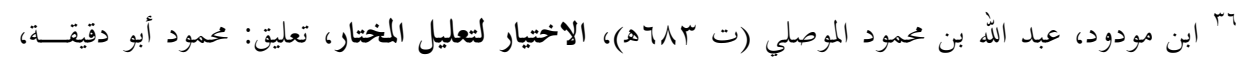

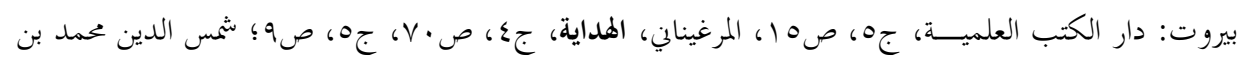


ذبح وذكر عليه اسم غير اسم الله؛ لأنَّهَ مما أهل به لغير الله لم وذلك لما فيه من

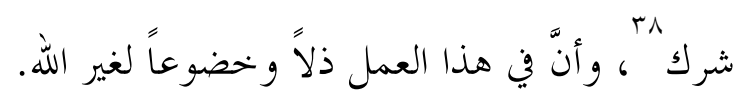

\section{(ب) المنخنة: (ب)}

وهي التي تخنق بحبل وشبهة و وهي التي تموت في خناقها و ولا خلاف بين

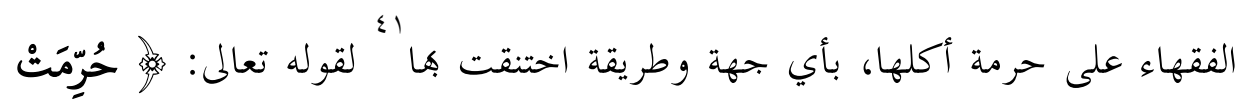

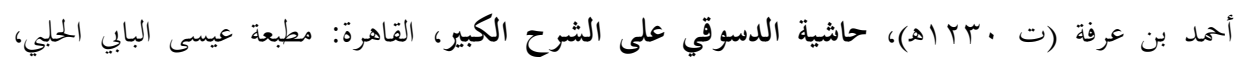

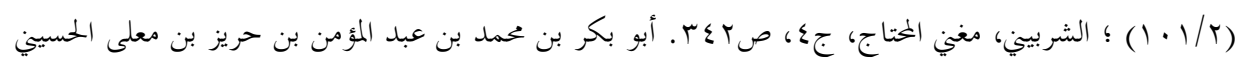

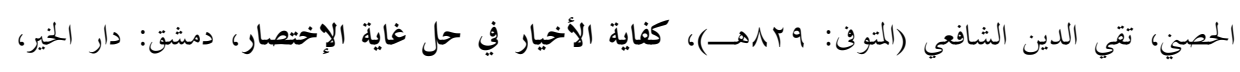

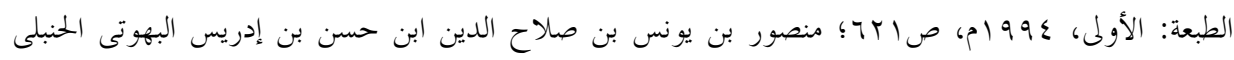

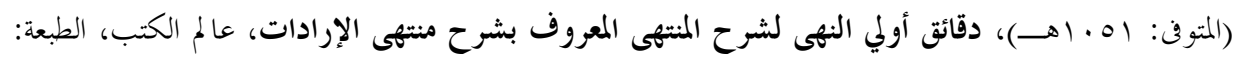

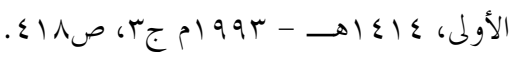

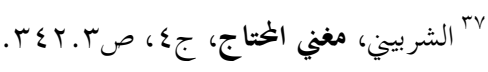

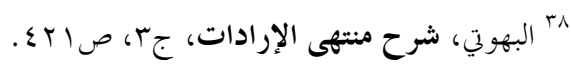

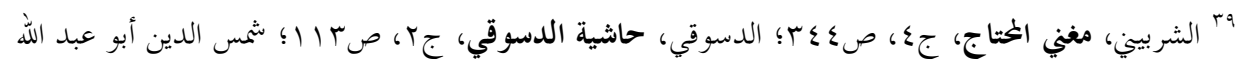

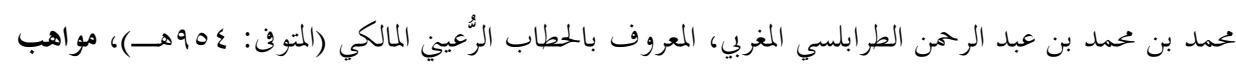

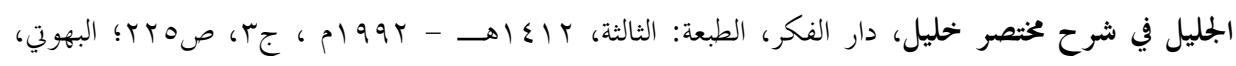

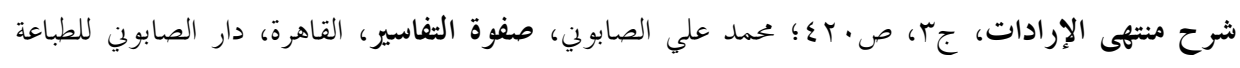

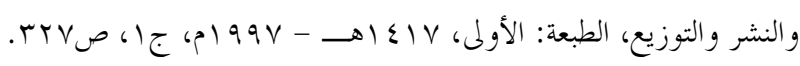

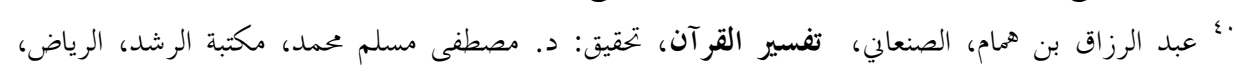

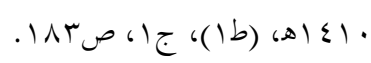

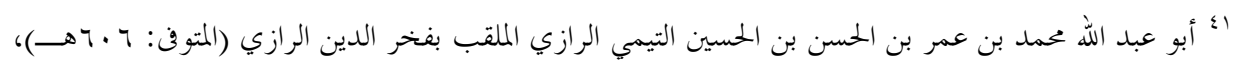

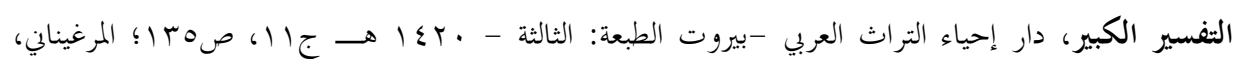

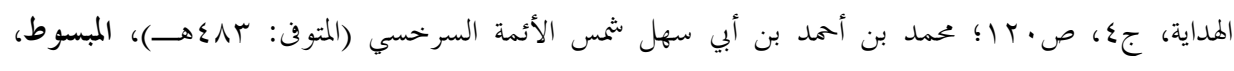

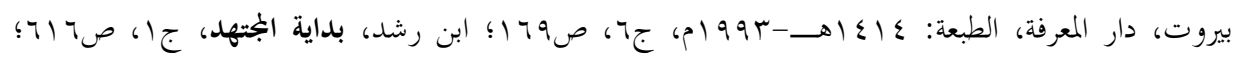




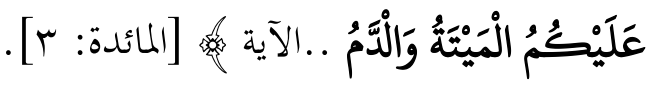

والمنخنقة محرمة إذا لم تلحق وهي فيها حياة وتذبح قبل أن تموت نتيجة

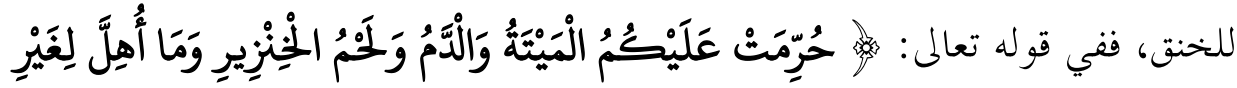

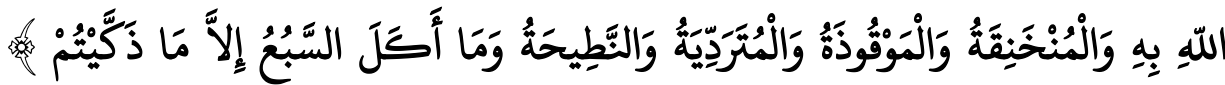

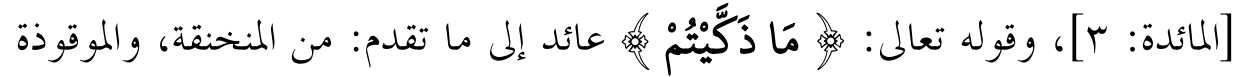
و المتردية والنطيحة وأكيلة السبع عند عامة العلماء، فمن ذبح الحيوان قبل أن يموت،

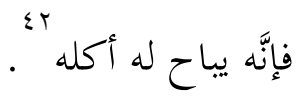

\section{(ج) الموقوذة والمتردية والنطيحة وما أكل السبع:}

الموقوذة: هي التي تضرب بخشبة وشبهـا حتى تشرف على الهلاك بـ و الوقذ

يعين الضرب، والموقوذة هي التي تضرب حتى الموت ــ و ويدخل في الموقوذة كل ما 乏० قتل منها على غير وجه الذكاة الشرعية قاله الجصاص

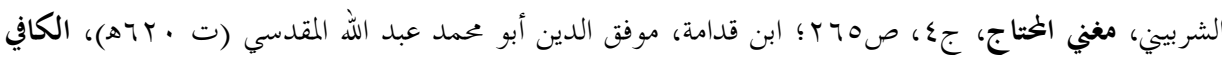

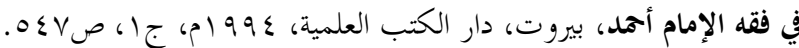

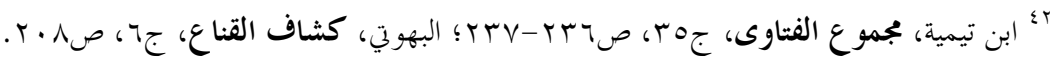

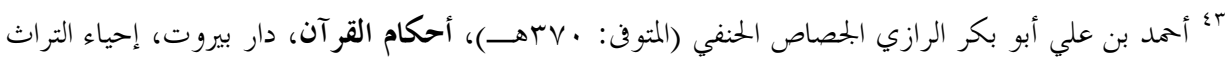

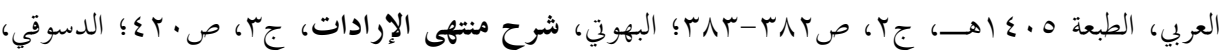

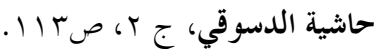
؛؛ شهاب الدين محمود بن عبد الله الحسيني الألوسي (المتوف: . لr اهــ) روح المعاني في تفسير القر آن العظيم

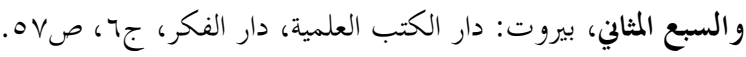

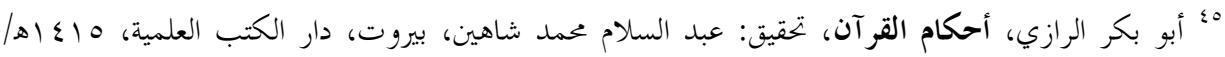

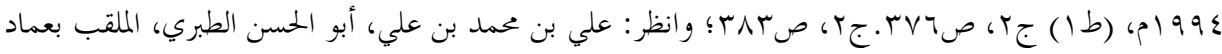

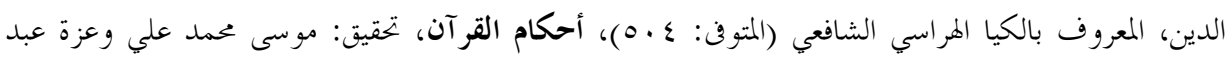

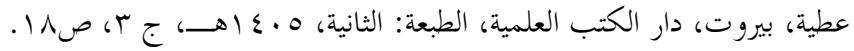




$$
\begin{aligned}
& \text { المتردية: هي التي تسقط من جبل أو مرتفع أو في بئر فتموت بـ وقيل المتردية } \\
& \text { هي الو اقعة في الردى أي الهلاك لو والأول أقوى لدلالة اللفظ عليه. }
\end{aligned}
$$

$\varepsilon \wedge$

النطيحة: هي الشاة تنطحها الشاة فتموتان، أو الشاة تنطحها البقر والغنم وهو قول ابن عباس رضي الله عنهما. وعرفها ابن عطية بقوله: (كل ما مات ضغطاً فهو نطيح)

وما أكل السبع: أي ما عدا عليه السبع وهو الحيوان المفترس وافترسه فمات " ولقد "هى عليه الصلاة والسلام عن أكل كل ذي ناب من السباع" " ويقصد بالسباع ما كان له ناب يعدو به على الحيوانات ويتقوى به عليها مُ .

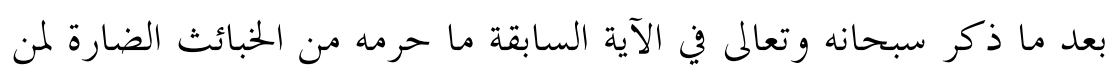
يتناولما في بدنه أو في دينه أو في كليهما، استثنى ما استثناه في حالة الضرورة فقال

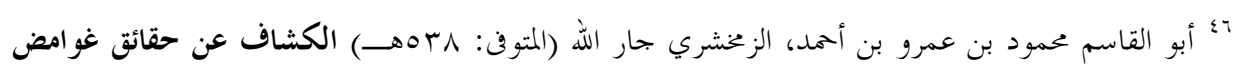

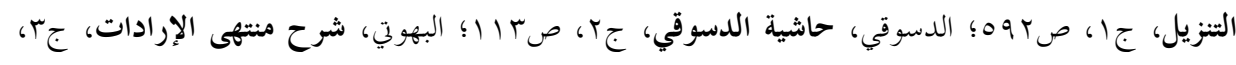

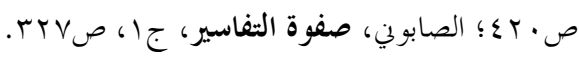

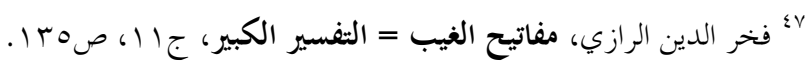

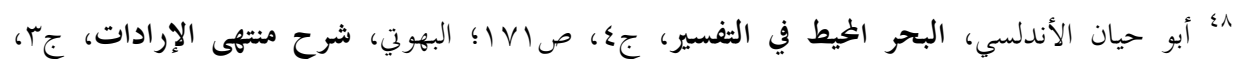
ص.

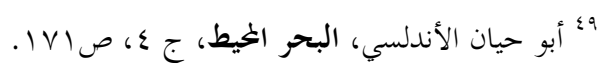

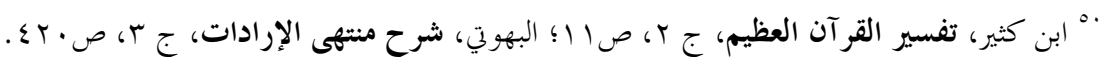

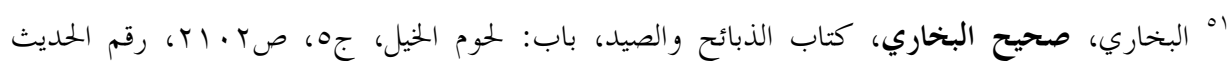
. (OY.V)

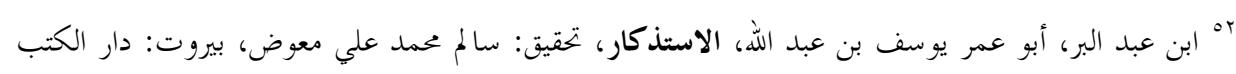

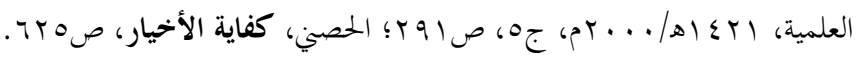


بعدها تبارك و تعالى: ع]، وقد قيل في الطيبات إذا الذبائح الحلال الطيبة، وقيل إذا ما أحل من كل شيء أن يصيبوه وهو الحلال من الرزق مقئ

ورأى الجصاص أن اسم الطيبات يطلق على الحلال وعلى المستلذة؛ وذلك ترك

$$
\text { لأنَّ ضد الطيب الخبيث وهو حرام، فالطيب إذاً حلال ؛ـ . }
$$

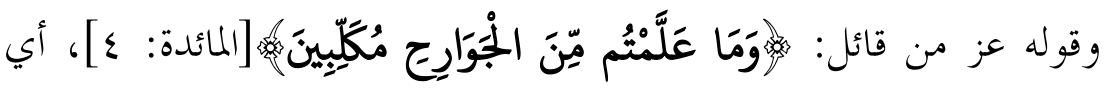

أحل لكم ما صدتموه بالجوارح وهي الكلاب والفهود والصقور وأشباهها، وهو مذهب الجمهور من الصحابة والتابعين والأئمة. وسميت هذه الحيوانات التي يصطاد

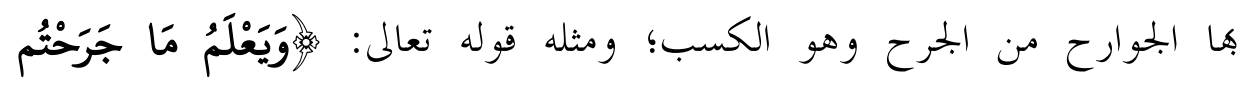
بِالنَّهَارِ

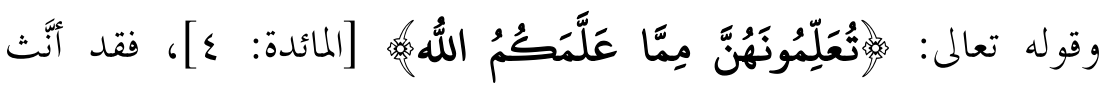

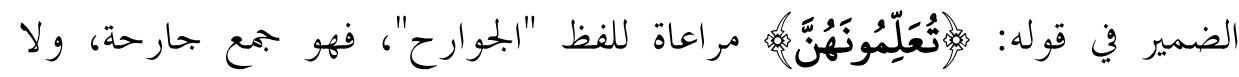
خلاف بين العلماء في اشتراط أمرين في تعليم الجوارح، الأول: أن يأتمر الحيوان إذا أُمر، و الثاني: أن ينزجر إذا زجر، فلا خلاف في هذين الشرطين في الكلاب ولا فيما هو في معناهما من سباع الوحوش •

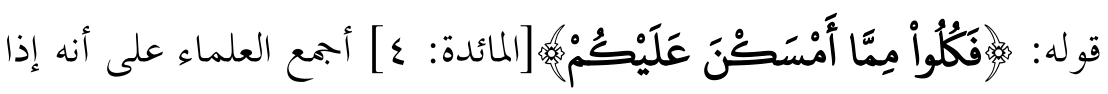
كان الجارح معلماً وأمسك على صاحبه، و كان قد ذكر اسم الله عليه عندما أرسله حلَّ له الصيد، وقد وردت الأحاديث المتعددة الروايات التي تدل على ذلك.

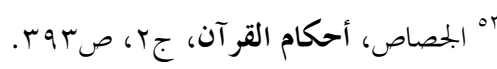

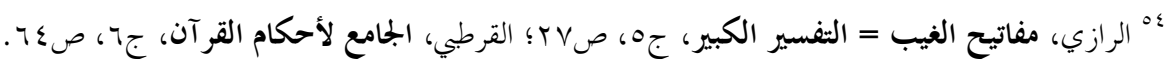

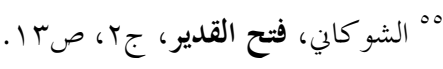




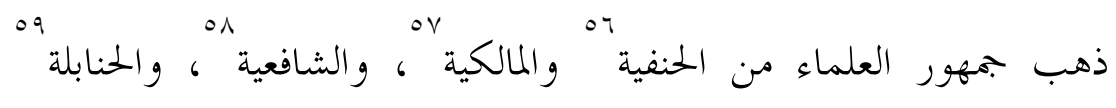
و الظاهرية "، إلى إباحة أكل ما صاد كل جارح معلم على العموم، سواء كان كلبًا أو من ذوي الأنياب من السباع كالأسد والفهد، أو المخالب من الطير كالبازي و الصقر ونهو هما.

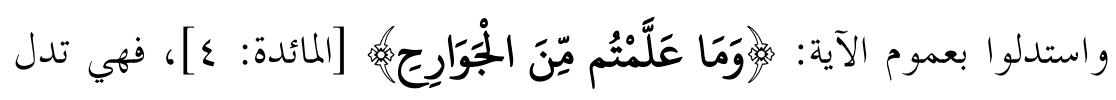

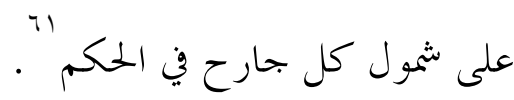

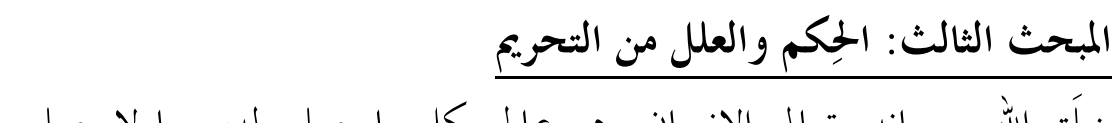

خلَق الله سبحانه وتعالى الإنسان وهو عالم بكل ما يصلح له، وما لا يصلح

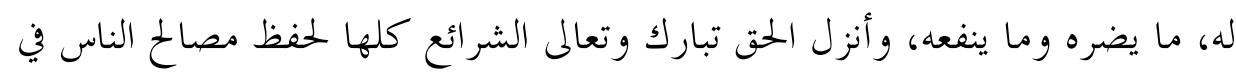
دنياهم، ولسعادهم في أخراهم، وهدفت هذه الشرائع السماوية إلى حفظ الضرورات الخمس: الدين و النفس، و العرض والمال و العقل.

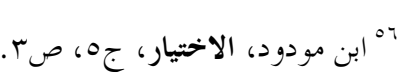

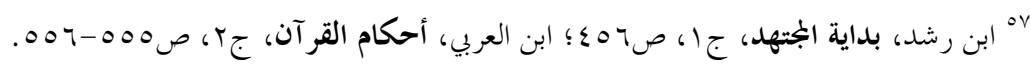

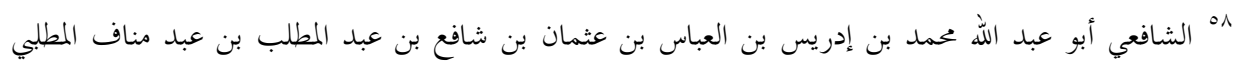

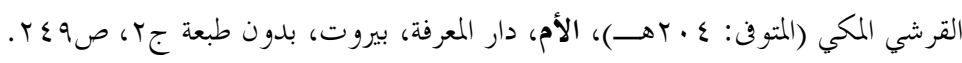

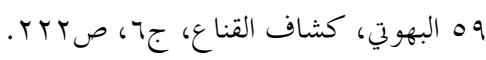

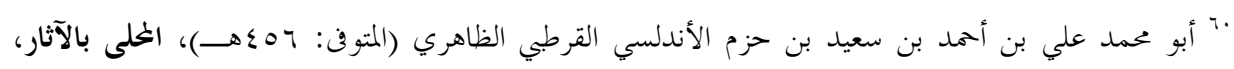

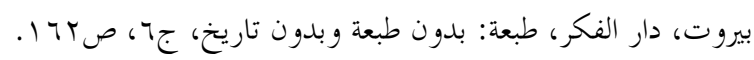

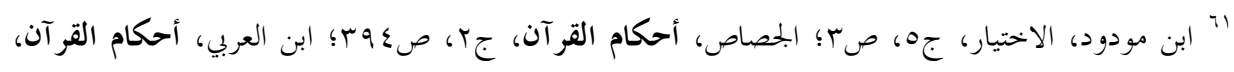

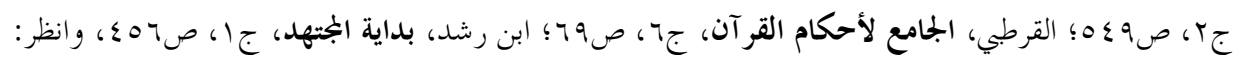

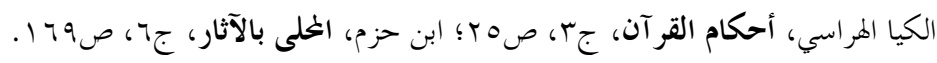


و الأصل في المسلم أنه يطيع الله فيما أمر، وينتهي عما فهى عنه، سواء أظهرت حكمته سبحانه في ذلك أم لم تظهر. والمسلم لا يجوز له رفض حكم الشريعة ولا التوقف في تنفيذه إذا لم تظهر له حكمته؛ بل عليه قبول الحلكم الشرعي في التحليل والتحريم متي ثبت النص ؛ سواء

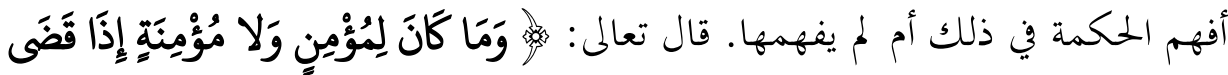

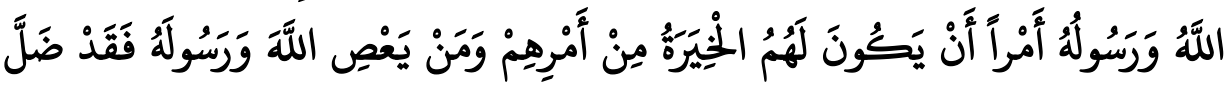

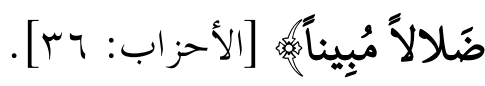
قال تعالى محذرًا المؤمنين من الخبائث، ومنفرًا أصحاب الطبع السليم منها:

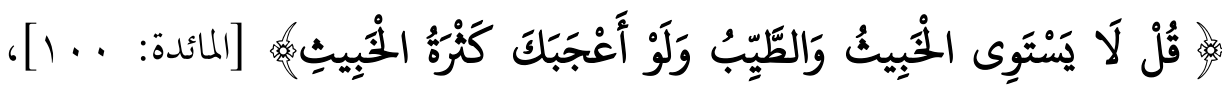

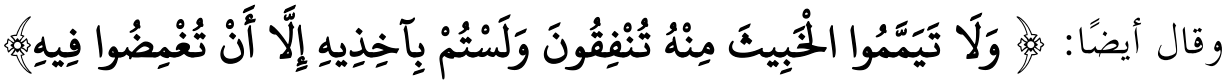

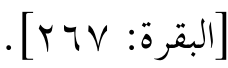
وجمع الله تبارك وتعالى الأمرين معًا (الترغيب في الطيبات والتنفير من المحرمات)، في جزء من آية واحدة، فبيَّن سبحانه بذلك جانبًا من جوانب إعجاز هذا

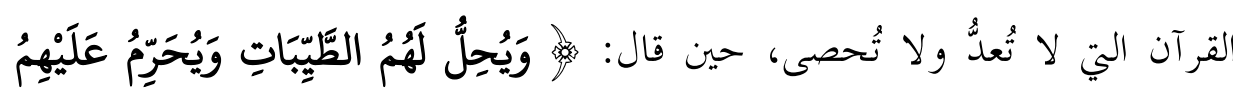

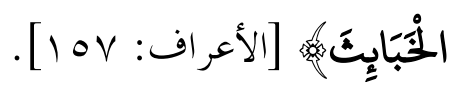
وفن تفسير قوله تعاله: الأنفس، فتكون الآية دالة على أن الأصل في كل ما تستطيبه النفس ويستلذه الطبع الحل، وقيل ما حرم عليهم من الأشياء التي حرمت عليهم بسبب ذنوهم من لحوم الإبل وشحوم الغنم والمعز والبقر، وقيل ما كانوا يحرمونه على أنفسهم في الجاهلية من البحائر و السو ائب و الوصائل و الحو امي.

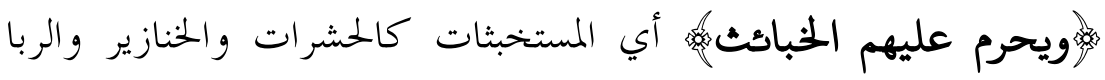
والرشوة وقال ابن عباس يريد الميتة والدم ولحم الحنزير وقيل هو كل ما يستخبثه 


$$
\text { الخرمات من الأطعمة الواردة في القر آن الكريم وعلاقتها بالأوبئة }
$$

الطبع أو تستقذره النفس فإن الأصل في المضار الحرمة إلا ما له دليل متصل بالحل ـ

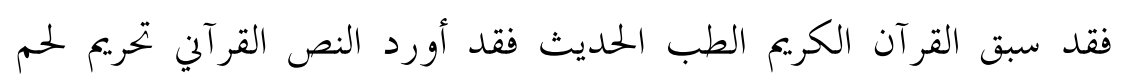

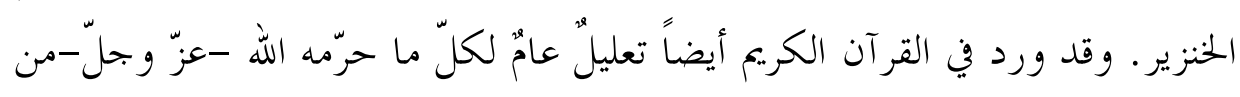

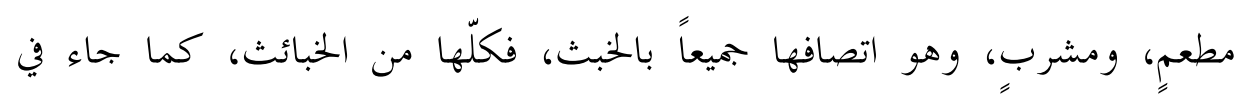

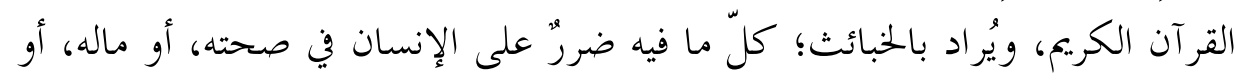

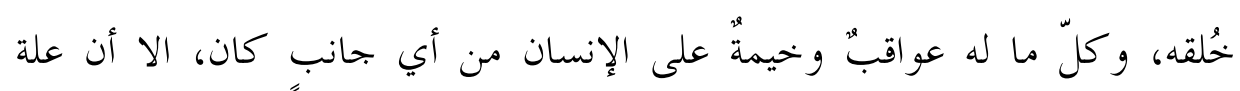

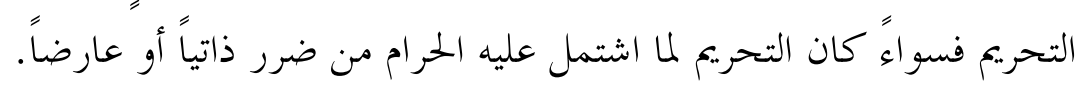

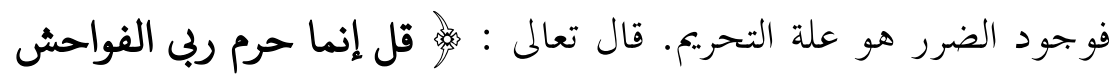
ما ظهر منها وما بطن والإثم والبنى بغير الحق وأن تشركوا بالله ما لم ينزل به سلطانا

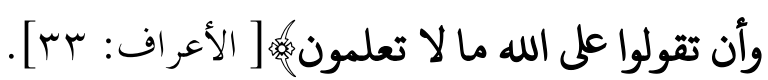

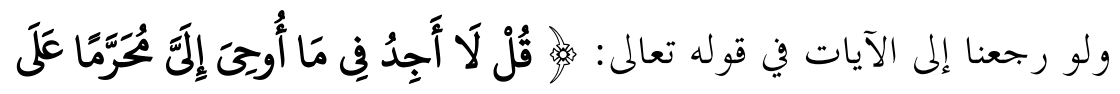

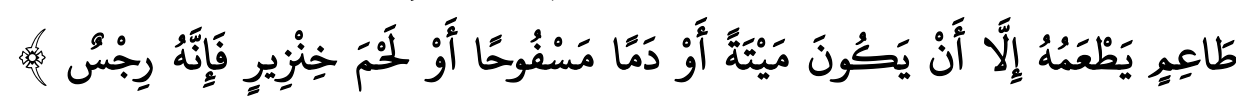

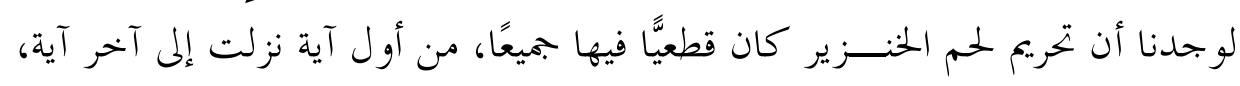

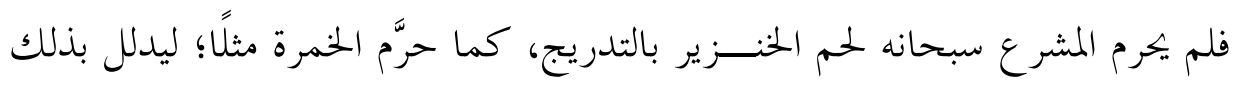
على مدى الضرر الذي يُسببه هذا الحيوان لآكليه من البشر.

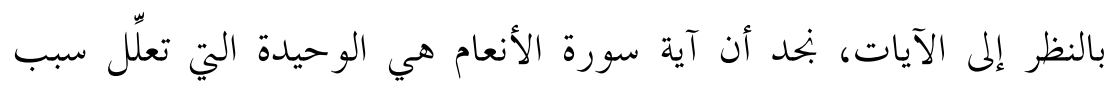

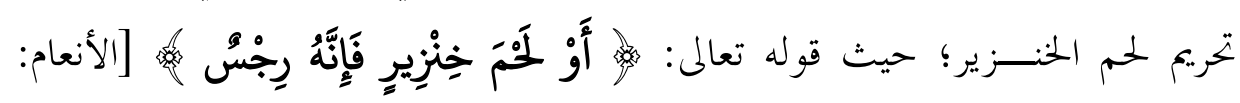

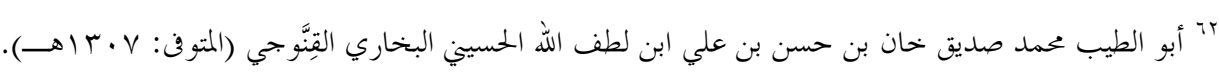

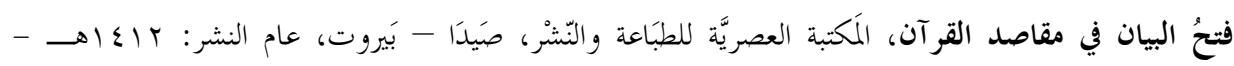

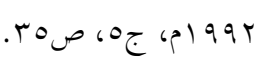




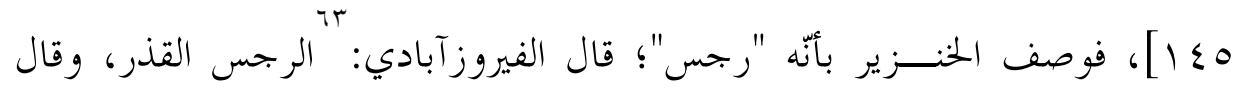

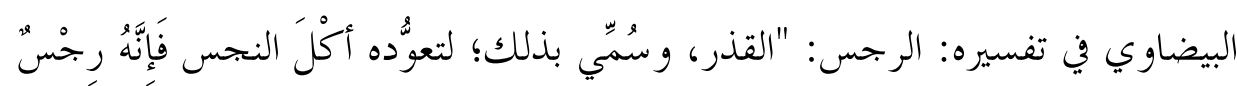

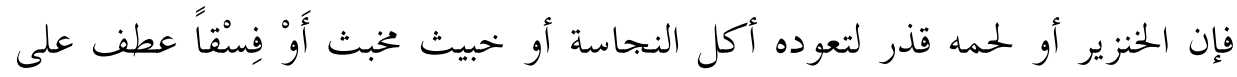

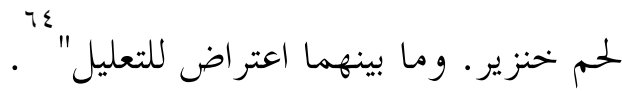

فالحق قد منع ما يضر الإنسان في بدنه، ومنع أيضا بعضا من الطيبات على بعض المخالفين كتأديب لهم. وبالنسبة لتحريم الحنزير، فقد شاءت إرادة الله عز وجل لإل أن يكشف لخلقه سر التحريم، فأثبت العلماء أن هناك أمراضاً في الخنزير لما فيه من فئرئ الضرر والاستقذار لملازمته للقاذورات ورغبته فيها، أما ضرره فقد أثبته الطب الحديث، إذ أثبت أن له ضررا يأتي من أكله القاذورات، فإن أكله يولد الديدان الشريطية كالدودة الوحيدة ودودة أخرى تسمى الشعرة الحلزونية وهى تنشأ من أكله الفئر ان الميتة، كما أثبت أن لحمه أعسر اللحوم هضما لكثرة الشحم في أليافه العضلية، وأن الموادّ الدهنية التي فيه تمنع وصول عصير المعدة إلى الطعام فيعسر هضم الموادّ الزلالية وتتعب معدة آكله ويشعر بثقل في بطنه واضطراب في قلبه، فإن ذرعه القيء فقذف هذه المو اد الحبيثة خفّ ضرره، وإلا هيجت المعدة وأصيب بالإسهال، ولو لا أن العادة قد جرت بتناول السموم أكلا وشربا وتدخينا ولو لا ما يعالجون به لحم الخنزير لتخفيف ضرره لما أمكن الناس أن يأكلوه و لا سيما أهل البلاد الحارة . بذلك تبقى العلة الذاتية التي لا تنفك عن لهم الخنزير في كونه بنساً وضاراً

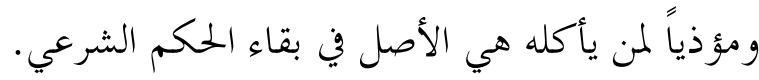

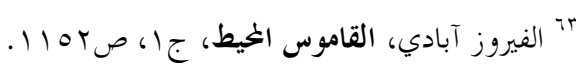

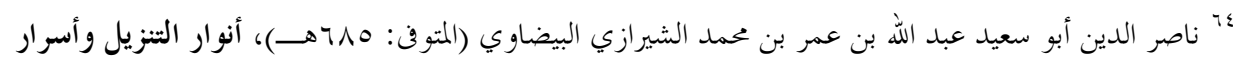

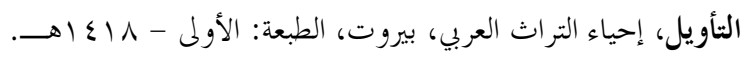

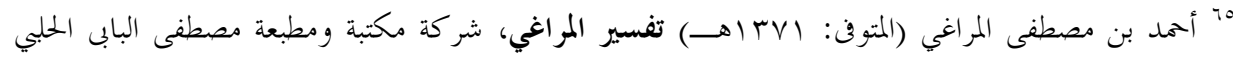

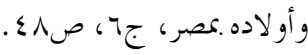


وقد تحققت بخاسة لحم الخنزير كما تحقق الضرر من أكل لحمه من خلال

الأبحاث العلمية العديدة وهذه بعض نتائجها:

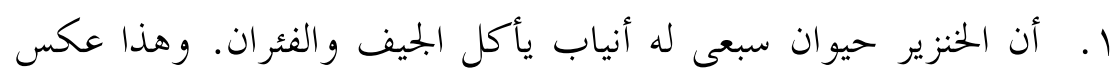

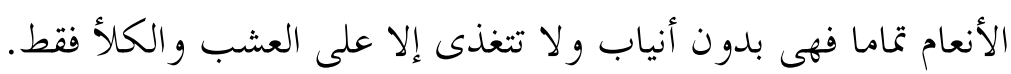
r. أن عدم وجود انزيمى Xanthan oxidase \&Uricase في بلازما الخنزير وقلة وجوده في الكليتين يجعله يحتفظ بكمية كبيرة من حض البوليك فن أنسجته فالحنزير يتخلص من r\% فقط من هذا الحمض و الباقى يختزن في جسده وهذا عكس الأنعام فهى تتخلص من حمض البوليك بكميات كبيرة لوجود (Xanthin oxidase في بلازما الأبقار وهو يقوم بتكسير حمض تهن

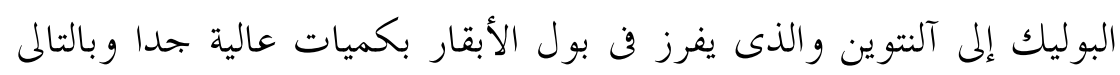

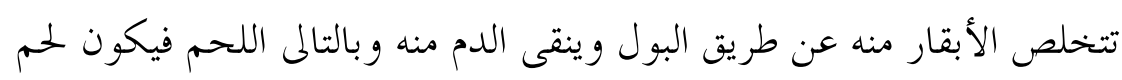
الأبقار طاهرا طيبا ـ كما يو جد فن بلازما الأغنام انزيم اليوريكاز (Uricase) والذى يقوم بتكسير حمض البوليك وتتخلص الأغنام منه عن طريق الكليتين مما يجعل لهم الأغنام أيضا طاهر الطيبا. r. أن كثرة وجود حمض البوليك فن دم وولمم الخنزير دليل على بناسته ولهذا وصفه ربنا عز وجل بأن رجس. ع. أن كمية انزيم اليوريكاز في كلى الأبقار حوالى ستة أضعاف الموجود

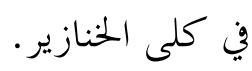
ه. أن الخنزير بطبعه الخبيث يأكل روثه المختلط ببوله وما به أيضا من مض البوليك يجعل تراكم هذا الحمض في لحمه بكميات كبيرة تضر بصحة الإنسان وهذا يدل على بناسة لحمه كما بين ربنا عز وجل في علة التحريم للحم الخنزير وهى أنه رجس وهذا من الإعجاز العلمي لهذه الآية ولتحريم 


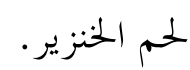

7. أن الحنزير يحتوى على . ه \% من لحمه دهنيات وأن هذه الدهنيات منها مب\% دهون مشبعة تراى جلسريد ولا يستطيع الإنسان هضمها بينما الأبقار تحتوى على ب \% فقط من الدهون وهى سهلة الفضم والأغنام تحتوى على V V V دهون أيضا سهلة الهضم وهذا يدل أيضا على الضرر المحقق من تناول 77 ل لحم لخنزير

ومن هنا تشير الدراسة بيان الإعجاز العلمي فن حرمة لحم الحنزير حيث إن كل هذه الأضرار التى موجودة في لخم ودهن ودم الحنزير تجعل الخنزير محرما لذاته

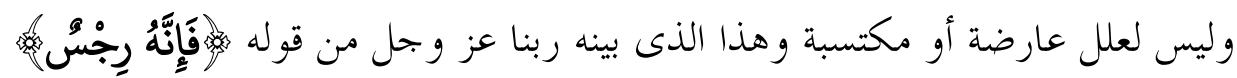
أي بحس، ضار ومؤذ ونتن ومن هنا يتضح وجه الإعجاز العلمي في هذا النص القرآي

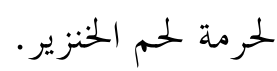

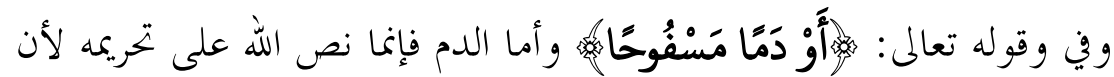
العرب كانت تأكل الدم، كانوا يأخذون المباعر فيملأوها دما ثم يشووها بالنار ويأكلوها، و حكمة تحريم الدم أن شربه يورث ضراوة في الإنسان فتغلظ طباعه ويصير كالحيوان المفترس، وهذا مناف لمقصد الشريعة، لأها جاءت لإتمام مكارم الأخلاق وإبعاد الإنسان عن التهور والهمجية، ولذلك قيد في بعض الآيات بالمسفوح أي المهراق، لأنه كثير لو تناوله الإنسان اعتاده ولو اعتاده أورثه . TV وقد اتفق الفقهاء على حرمة الدم وبنحاسته، وأنَّه لا يؤكل ولا ينتفع به؛ لأنَّه

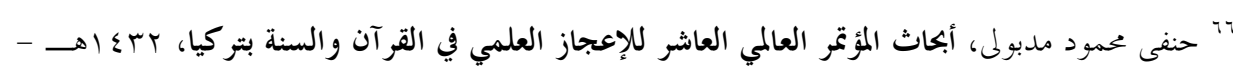

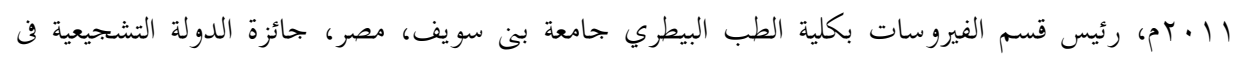

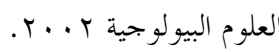

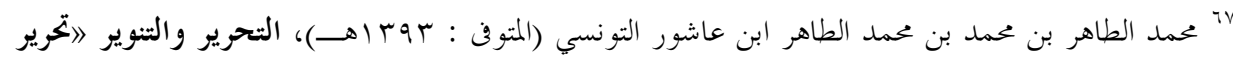

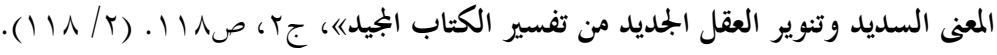


يحمل فضلات الجسمه، بما فيها من أمور ضارة (كالجر اثيم، والميكروبات، وغيرهما مما

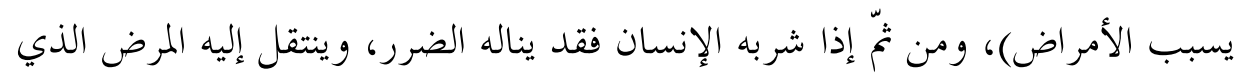

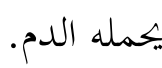

وهو الدم الذي يخرج من الذبيحة عند ذكاها، فإنه الدم الذي يضر احتباسه

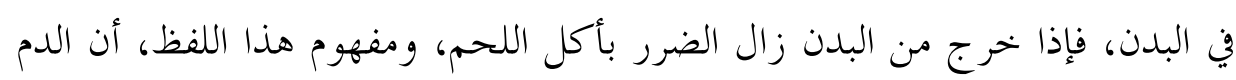

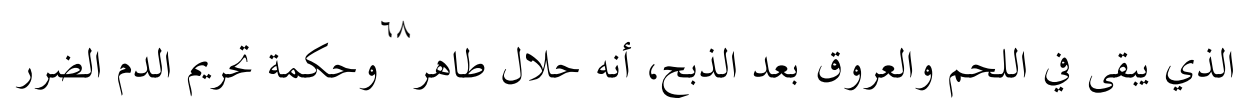
والاستقذار أيضا. أما الضرر فلأنه يعسِّ الهضم، ويحمل كثيرا من الموادّ العفنة التي

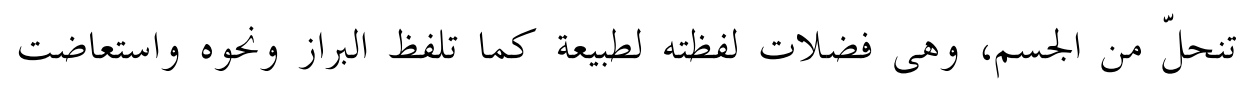
عنها بمو ادّ جديدة من الدم، وقد يكون فيه جر اثيم بعض الأمراض المعدية وهى تكون

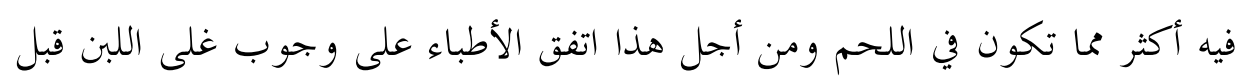

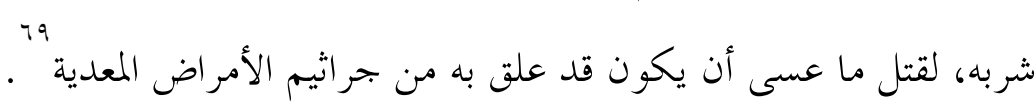
$v$.

لا خلاف على أن الميتة محرمة على المسلمين ل وقد حرمتها سورة المائدة

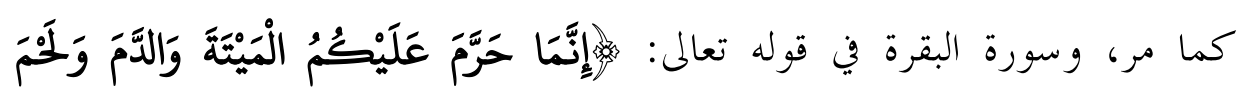

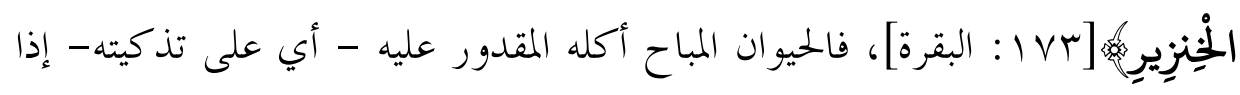

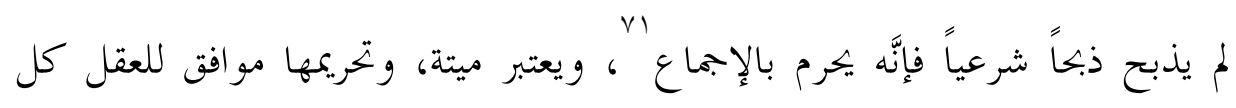

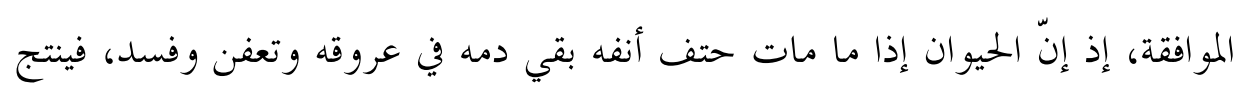

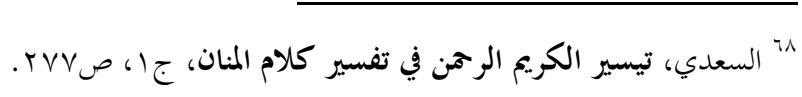

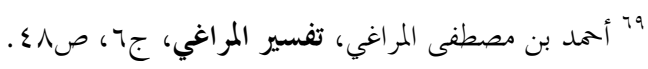

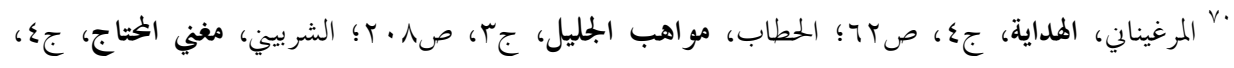

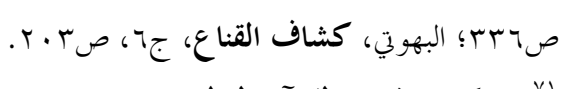

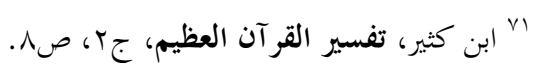


و اعلم أن حكمة تحريم الميتة فيما أرى هي أن الحيوان لا يموت غالبا إلا وقد

أصيب بعلة، و العلل مختلفة، وهي تترك في لحم الحيوان أجزاء منها فإذا أكلها الإنسان

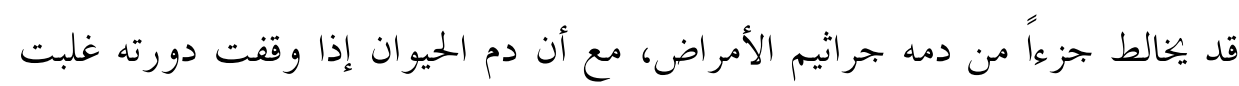

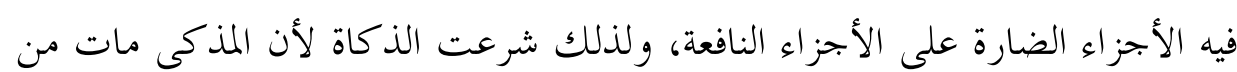
غير علة غالبا و لأن إراقة الدم الذي فيه بتعل لحمه نقيا مما يخشى منه أضرار ل . ل قد استثنى الله عزّ وجل المنخنقة، و الموقوذة، و المتردية، والنطيحة وما أكل

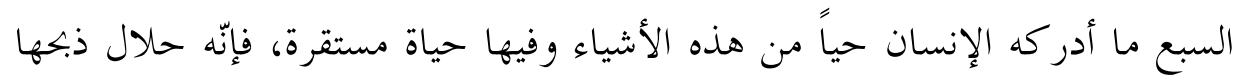
وأكلها؛ لأنّها توفرت فيها شروط الإباحة وهي الذكاة الشرعية. أمّا ما أدركها

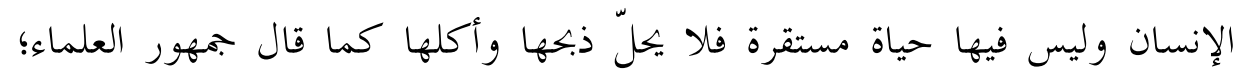

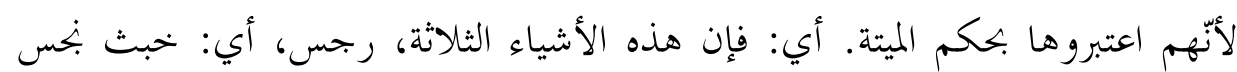
مضر، حرمه الله لطفا بكم، ونزاهة لكم عن مقاربة الخبائث. ومع هذا، فهذه الأشياء المحرمات، من اضطر إليها، أي: حملته الحاجة و الضرورة إلى أكل شيء منها، بأن لم يكن عنده شيء وخحاف على نفسه التلف.

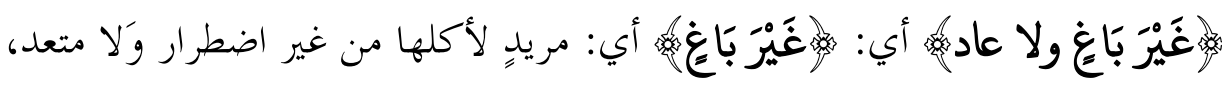

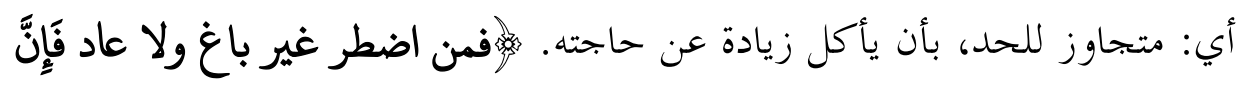

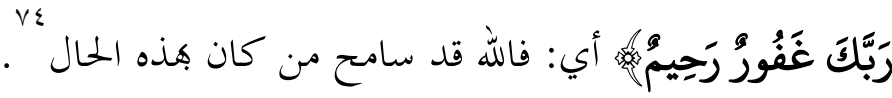

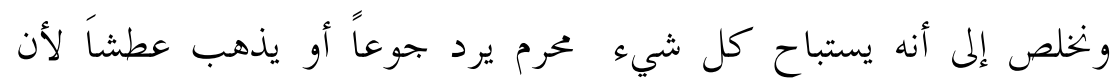

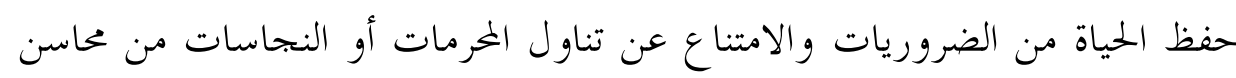

$$
\begin{aligned}
& \text { Vr }
\end{aligned}
$$

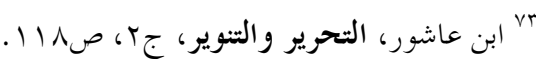

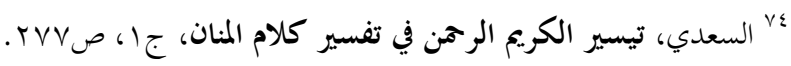


العادات وهو .مثابة التكملة بحيث يُنقص الأصل وهو الحياه ؛ فيكون تناول المررمات أولي من الامتناع ؛ حفظاً للحياة، ودفعاً للضرر الأكبر بتحمل الضرر الأقل.

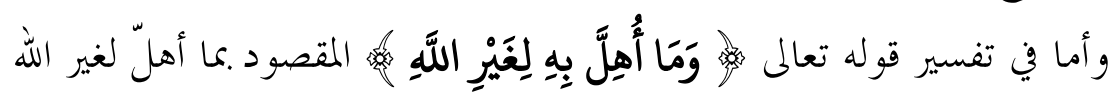

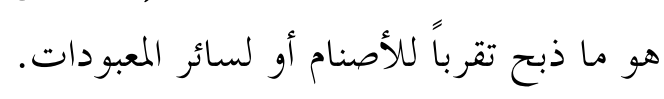

بالإضافة إلى ما ذُبح وسُمّي عليه غير اسم الله عزّ وجل؛ وَّل وهذا يشمل نوعين:

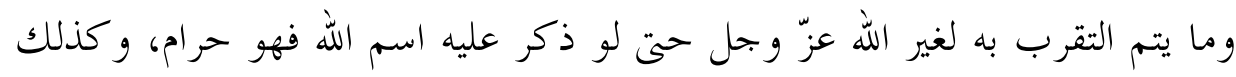

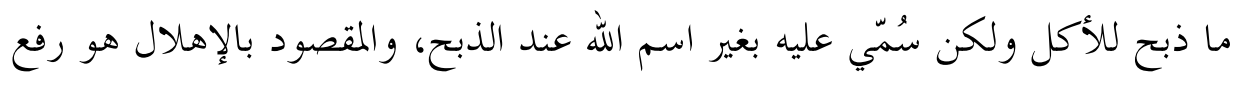
الصوت بغير اسم الله.

قال ابن عباس وغيره: المراد ما ذبح للأنصاب والأوثان، ووأُهِلَّ معناه صيح، الهِ ومنه استهلال المولود، وجرت عادة العرب بالصياح باسم المقصود بالذبيحة، وغلب ذلك في استعمالهم حتى عبر به عن النية التي هي علة التحريم. أي: إلا أن تكون

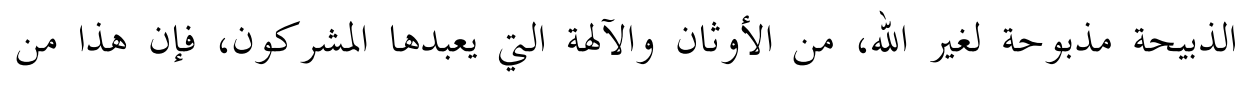
الفسق الذي هو الخروج عن طاعة الله إلى معصيته . vo والمراد هنا ما ذكر عليه اسم غير الله تعالى كاللات والعزى إذا كان الذابح وثنياً، و النار إذا كان الذابح بجو سياً. ولا خلاف في تحريم هذا وأمثاله. و مثله ما يقع من المعتقدين للأموات من الذبح على قبورهم، فإنه مما أهل به إله لغير الله، ولا فرق بينه وبين الذبح للوثن، قال بحاهد: يعين ما ذبح لغير الله، أخرجه ابن أبي حاتم، وفي تفسير النيسابوري للنظام قال العلماء لو أن مسلماً ذبح ذبيحة

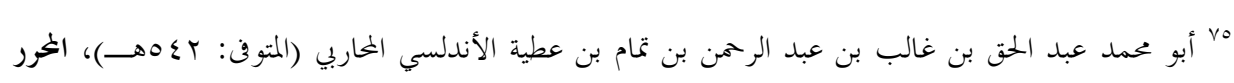

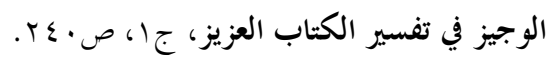


وقصد بذبها التقرب إلى غير الله صار مرتداً، وذبيحته ذبيحة مرتد انتهى . VT أما ما أهل به لغير الله. أي ما توجه به صاحبه لغير الله فهو مررم، لا لعلة فيه، ولكن للتوجه به لغير الله. محرم لعلة روحية تنافي صحة التصور، وسلامة القلب، وطهارة الروح، وخلوص الضمير، ووحدة المتجهه. فهو ملحق بالنجاسة المادية و القذارة الحقيقية على هذا المعنى المشترك للنجاسة. وهو ألصق بالعقيدة. من هنا تتجلى علاقة التحليل و التحريم في هذه الآيات، بالحديث عن وحدانية الله ورحمته كذلك في الآيات السابقة. فالصلة قوية ومباشرة بين الاعتقاد في إله واحد، وبين التلقي عن أمر الله في التحليل والتحريم. من سائر المرمات قبله. وقد حرص الإسلام على أن يكون التو جه الله و حده بلا شريك.

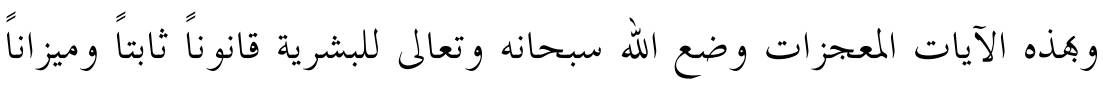
دقيقاً يمكننهم من قياس كل المستجدات بعد زمن الرسول صل الله علية وسلم وإلى ولى قيام الساعة، ليعرفوا طيبها من خبثيها، و نافعها من ضارها، فيقبلوا علي الطيبات ويبتعدوا عن الخبائث و المحرمات، فأكد بكل وضوح وجاء أن شريعة الإسلام صالحة

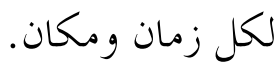

\section{الحاتمة:}

أظهرت هذه الدراسة إدراك الشريعة الإسلامية المسبق للعلوم البشرية من

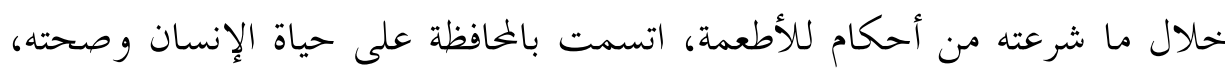
و التخفيف عنه، والرأفة به، وهي أيضاً توثق صلته ببارئه في كل الأمور.

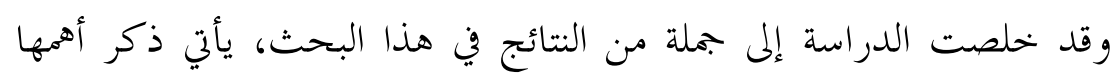
فيما يلي: 
1 - ثبوت ارتباط الحقائق القرآنية بكل جزئيات حياة الإنسان .بما فيها المتلعقة بغذائه وصحته.

r - حل ههيمة الأنعام وهي الأزواج الثمانية - من الإبل والبقر والضأن

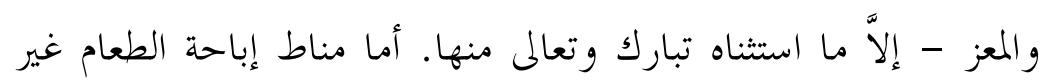
المسكوت عن حكمه في الشرع؛ فكونه طيباً لا يضر جسم الإنسان، والمرجع في ذلك الطب لا العرف، فإذا ثبت من ناحية علمية وطبية عدم و جود ضرر من أكله فلا بأس به، وإلا فلا يصح ذلك.

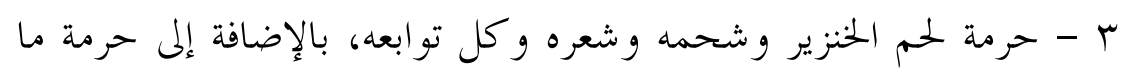

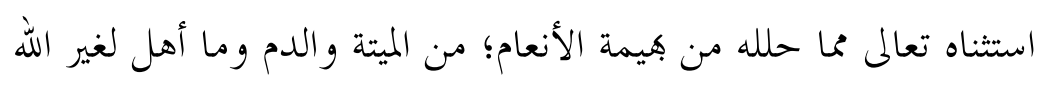

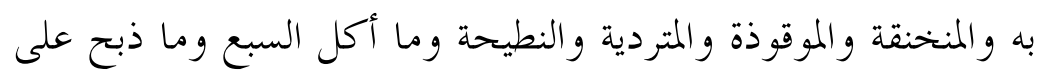

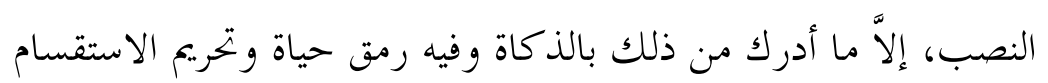
بالأزلام.

ع - علة وجوب التذكية هي إذار الدم بقطع الودجين، والحكمة من ذلك بلك

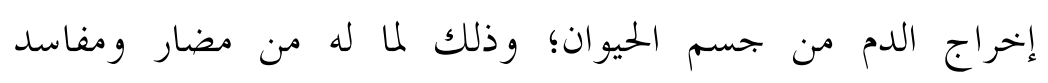
لإلسنسان.

ه - إباحة ما حرم من الأطعمة والأشربة في حالة الاضطرار وخشية الموت بشرط عدم ابتغاء أكلها وعدم الرغبة فيه أصلاً، وبشرط علة عدم الأكل

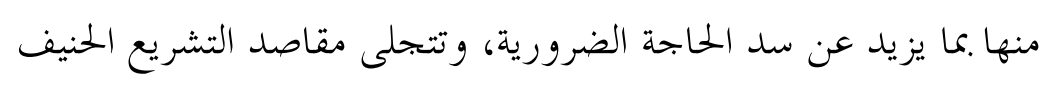
في هذه الإباحة بأعظم حال فهي ترسخ حفظ الضروريات، وبخاصة حفظ النفس البشرية. 7 - حل الطيبات وحرمة الخبائث، وحل الصيد بالكلاب و سباع البهائم و الطير إذا علمت وأرسلت من صاحبها المسلم وذكر اسم الله عليها 
V - كل ما حرم في هذه السورة المبار كة إنما حظر لمقصد شرعي جليل وهو

حفظ النفس، فحكمة التشريع تتجلى بصورة هية فريدة في هذه الآيات التي أباحت لنا ما ينفع من الطيبات، و حرمت علينا ما يضر. التو صيات:

في هاية هذا البحث توصي الباحثة بما يأتي:

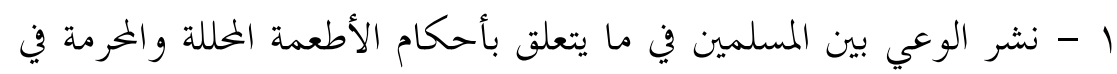

ضوء المستجدات المعاصرة.

r - الاهتمام بفحص اللحوم المستوردة من خارج بلاد المسلمين، وتشكيل

لجان خاصة للتأكد من مطابقتها للشروط الشرعية السابقة كلها.

ب - استيراد الحيوانات مأكولة اللحم حية وذبحها في بلاد المسلمين تفاديا

للوقوع في المخظور شرعا من إشكالات كثيرة.

و آخر دعو انا أن الحمد لله رب العالمين.

المصادر و المراجع

Abū al-qāsm mḥmūd bn 'mrū bn aḥmd, al-zmḥšrī ğār al-lh (ālmtūfi: 538.), al-kšāf 'n ḥqā' iq ġwāmọ al-tnzīl.

Abū al-țî̀ mḥmd ṣdīq hāan bn ḥsn bn 'lī abn lṭ̂ al-lh al-ḥsīnī al-bhārī alqinawūğì (ālmtūfi: 1307h.). ftḥu al-bīān fì mqāṣ̂d al-qr'àn, al-maktbë al-

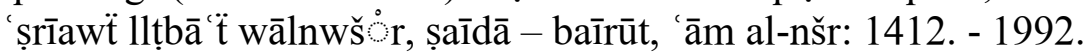

Abū al-ūlīd mḥmd bn aḥmd ršd (ālḥ̂ìd) al-qrṭbī (t 595), bdāït al-mğthd ūnhāït al-mqtṣd, bīrūt, dār al-m'rffi, (ṭ7), 1405h/ 1985. 


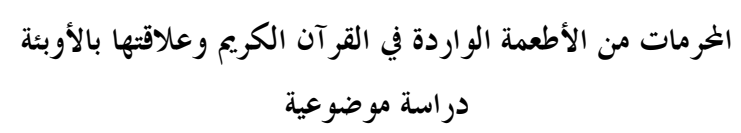

Abū 'bd al-lh mḥmd bn aḥmd bn abī bkr bn frḥ al-' anșārī al-ḥzrğĩ šms al-dīn al-qrțbī (ālmtūfi: 671.), al-ǧām ' l'aḥkām al-qr'ān, tfsīr al-qrṭ̂ī, dār al-ktb al-mșrït, al-qāhr̈̈, al-țb đ̈t: al-țānït, 1384. - 1964.

Abū 'bd al-lh mḥmd bn 'bd al-lh (321-405), al-mstdrk 'li al-ṣ̣ịḥin, tḥqīq: mṣṭti ‘bd al-qādr 'ṭā, bīrūt, dār al-ktb al- 'lmīit, 1411/1990, (ṭ̂).

Abū 'bd al-lh mḥmd bn ğmāl al-dīn 'bd al-lh bn 'lī al-ḥršī al-mālkī, šrḥ

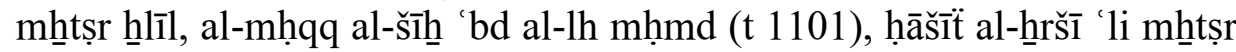
sīdī hlî̀l, bīrūt, dār al-fkr.

Abū 'bd al-lh mḥmd bn 'mr bn al-ḥsn bn al-ḥsīn al-tīmī al-rāzì al-mlqb bfhnr al-dīn al-rāzī (ālmtūfi: 606.), al-tfsīr al-kbīr, bīrūt, dār ihīā' al-trāt

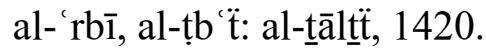

Abū 'bd al-rḥmn al-ḥlīl bn aḥmd bn 'mrū bn tmīm al-frāhīdī al-bṣrī (ālmtūfi: 170.), ktāb al-'īn, tḥqīq al-mḥqq: d mhdī al-mh̄zūmīe d ibrāhīm al-sāmrā'̀̄, dār ūmktbë al-hlāl.

Abū bkr bn mḥmd bn 'bd al-mu'mn bn ḥrīz bn m 'li al-ḥsīnī al-ḥṣnī, tqūi

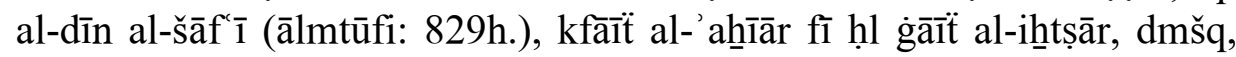
dār al-h̄īr, al-ṭb ‘̆t: al-'aūli, 1994.

Abū hịīn, mḥmd bn īūsf al-'andlsī al-girnātị (t 774), al-bḥr al-mhịị fī altfsīr, a tni bh șdqī mḥmd ğmīl, bīrūt, dār al-fkr, 1412/1992, (ț1).

Abū mḥmd 'bd al-ḥq bn gāalb bn 'bd al-rḥmn bn tmām bn 'ṭịt al-' andlsī al-mḥārbī (ālmtūfí: 542.), al-mḥrr al-ūḡìz fì tfsīr al-ktāb al- 'zīz.

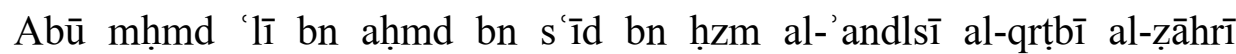

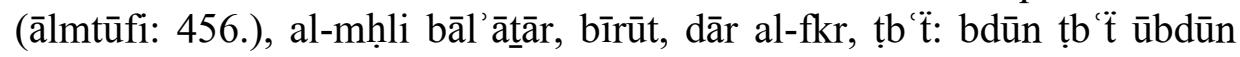
tārīh.

Aḥmd bn fārs al-qzwynī mqāyis al-lg̣t, tḥqīq: 'bdālslām hārūn, atḥād alktāb al-'rb, 1423.

Aḥmd bn 'lī abū bkr al-rāzī al-ğṣāṣ al-ḥnfī (ālmtūfi: 370.), ạ̣kām al-

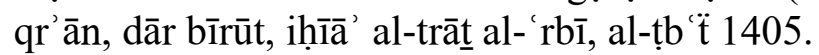


Aḥmd bn mḥmd bn 'lī al-fîumī țm al-ḥmwy, abū al- 'bās (ālmtūfi: nḥū 770h), al-mṣbāḥ al-mnīr, bīrūt, al-mktbë al-' lmït.

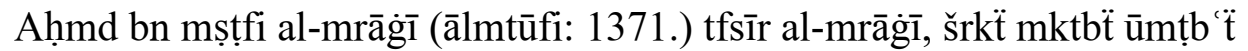
mșṭi al-bābi al-ḥlbī ū' aūlādh bmṣr.

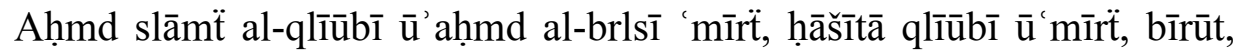
dār al-fkr 'dd al-'ağzā': 4 al-ṭb '̈̈: bdūn ṭb ‘̈t, 1415.- 1995.

Al-'alūsī, abū al-f̣̣l šhāb al-dīn al-sīd mḥmūd al-bg̉dādī (t 1270), rūḥ alm ānī fî tfsīr al-qr'ān al- 'ẓīm wālsb' al-mtān̄ī, bīrūt, dār al-fkr.

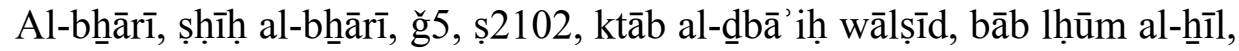
rqm al-ḥdì (5207).

al-bhūtī, kšāa al-qnā' 'n mtn al-iqnā', bīrūt, dār al-fkr, 1402/ 1982, (ț1).

Al-dsūqī, al- 'lāmë šms al-dīn mḥmd bn aḥmd bn 'rfẗ (t 1230), ḥāšïit aldsūqī 'li al-šrḥ al-kbīr, al-qāhrï, mṭb ‘̈̈ 'īsi al-bābī al-ḥlbī.

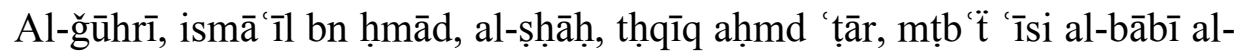
ḥlbī, al-qāhrï, 1972.

Al-Nwuī, thd̄īb al-'asmā' wāllg̀ăt, dār al-ktb al- 'lmīt, bīrūt - lbnān ( d.ṭ).

Al-qrṭbī, al-imām abū 'bd al-lh mḥmd bn aḥmd al-'anșārī al-mālkī (t 671), al-ğām ' l'aḥkām al-qr'ān, bīrūt, mu’ ssẗ al-mnāhl, dmšq, mktb̆̈ alġzālī.

Al-šăf'ī abū 'bd al-lh mḥmd bn idrīs bn al- 'bās bn 'țān bn šăf' bn 'bd al-mṭlb bn 'bd mnāf al-mṭlbī al-qrš̄i al-mkī (ālmtūfi: 204.), al-'am, bīrūt, dār al-m'rfit, bdūn ṭb ‘̆t.

Al-sīụṭi, al-imām 'bd al-rḥmn bn al-kmāl ğlāl al-dīn (t 911), al-dr almntūr, bīrūt, dār al-fkr, 1993.

Al-ṣn 'ānī, al-imām 'bd al-rzāq bn hmām, tfsīr al-qr'ān, tḥqīq: d. mṣṭfi mslm mḥmd, mktbë al-ršd, al-rīâḍ, 1410, (ṭ̂).

Al-šūkānī, mḥmd bn 'lī bn mḥmd (t 1255), ftḥ al-qdīr al-ğām ' bīn fnī alrwāït wāldrāït mn 'lm al-tfsīr, ḍbṭh ūṣḥ̣h aḥmd 'bd al-slām, bīrūt, dār 


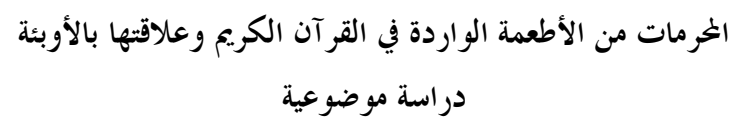

al-ktb al- 'lmït, 1415/1994, (ț1).

Al-ṭbrī, al-imām mḥmd bn ğrīr bn īzīd bn hhāld (224-310), ğām ' al-bīān 'n t' awyl aī al-qr' ān, bīrūt, dār al-fkr, 1405/1985.

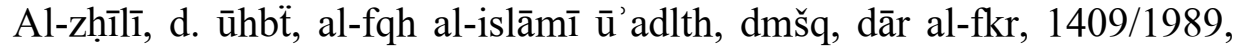
(ṭ).

'bd al-rḥmn bn mḥmd bn slīmān al-md 'ū bšin̄ini zādh, ī'rf bdāmād afndī (ālmtūfi: 1078.), mğm ' al-'anhr fì šrḥ mltqi al-'abḥr, dār iḥīà' al-trât al-

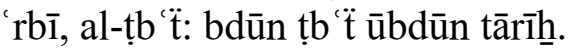

'bd al-rḥmn bn nāṣr bn 'bd al-lh al-s' dī (ālmtūfi: 1376.), tīsīr al-krīm alrḥmn fì tfsīr klām al-mnān, mu’ ssï al-rsālet, al-ṭb '̈̈: al-' aūli 1420 -2000.

Brhān al-dīn 'lī bn abī bkr šịn al-islām (t 593) al-mrgīinānī, al-hdāìt.

Ğlāl al-dīn al-sīutṭi (849-911), ūğlāl al-dīn al-mḥlī (791-864), tfsīr alğlālīn, dār al- rbït, mṭ̂ù āt dār mrwān.

Ibn al- 'rbī, al-imām abū bkr mḥmd bn 'bd al-lh, ạ̣kām al-qr'ān, tḥqīq: mḥmd 'lī al-bğāâwy, bīrūt, dār al-m 'rft, 1407/1987, (ṭ1).

Ibn 'bd al-br, abū 'mr īūsf bn 'bd al-lh, al-āstḍkār, tḥīiq: sālm mḥmd 'lī m 'ụḍ, bīrūt, dār al-ktb al- 'lmït, 1421h/2000m.

Ibn ḥ̆gr, aḥmd bn 'lī al-'sqlānī (t 852), al-iṣābë fĩ tmyiz al-ṣhābë, tḥqīq: 'li mḥmd al-bğāwy, bīrūt, dār al-ğlīl, 1412h, (ț1), rqm al-trğmë (1885).

Ibn kṭīr, al-imām al-hāạz̨ 'mād al-dīn abū al-fdā' ismā '̄il al-qršì al-dmšqī (t 774h), tfsīr al-qr'ān al-' ẓìm, bīrūt, dār al-fkr, 1412h/1992.

Ibn mūdūd, 'bd al-lh bn mḥmūd al-mūṣlī (t 683), al-āhntiār lt' līl al-mhntār, t' līq mḥmūd abū dqīq.êt, bīrūt, dār al-ktb al- 'lmī.ẗ.

Ibn qdāmë, mūfq al-dīn abū mḥmd 'bd al-lh al-mqdsī (t 620), al-kāfì fì fqh al-imām aḥmd, bīrūt, dār al-ktb al- 'lmïit, 1994.

Ibrāhīm bn 'bd al-lh al-mzrū' $\overline{1}$, aḥkām al-ḥīwānāt, mā ìğūz aklh, ūmā lā īğūz, qsm al-fqh ... mqāl ....... tārīh al-iḍâft: al-hֵmīs, 23/11/2017 - 
14:07.

'lī bn mḥmd bn 'lī, abū al-ḥsn al-ṭbrī, al-mlqb b'mād al-dīn, al-m 'rūf bālkīā al-hrāsī al-šăf'ī (ālmtūfi: 504), aḥkām al-qr'ān, tḥqīq: mūsi mḥmd

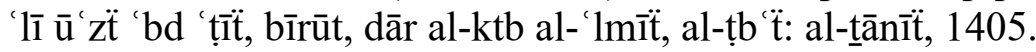

Mğd al-dīn mḥmd bn ī'qūb al-fî̀ūz abādī, al-qāmūs al-mḥịt, bīrūt: Mu'ssẗ al-rsālt llṭbā ‘̆ wālnšr wāltūzī', ṭ 8 142. . 2005 ğ/1 ș1152.

Mḥmd al-'amīn bn mḥmd al-mḥtār bn 'bd al-qādr al-ğknī al-šnqīṭ̣̂

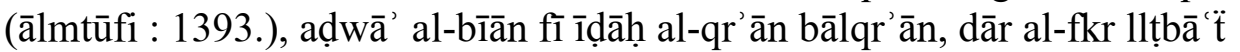
wālnšr wāltūzī' , bīrūt - lbnān, 1415. - 1995 (7/ 496).

Mḥmd al-țāhr bn mḥmd bn mḥmd al-țāhr bn 'āšūr al-tūnsī (ālmtūfi : 1393.), al-thrīr wāltnwyr «tḥrīr al-m'ni al-sdīd ūtnwyr al- 'ql al-ğgīid mn tfsīr al-ktāb al-mğīd», (2/ 118).

Mḥmd bn aḥmd bn abī shl šms al-'a imë al-srhnsī (ālmtūfi: 483.), almbsūt, bīrūt, dār al-m 'rfẗ, al-ṭb ‘̆t: 1414.-1993.

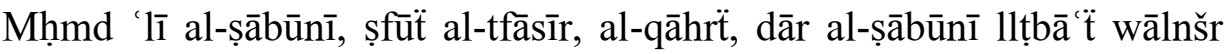
wầltūzî̀', al-ṭb '̆̈: al-’aūli, 1417. - 1997.

Mḥmd mtūlī al-š rāwy (ālmtūfi: 1418.), tfsīr al-šs rāwy, mțāb a ahbār alīūm ... (2.. 712).

Mnșūr bn īūns bn ṣlāḥ al-dīn abn ḥsn bn idrīs al-bhūti al-ḥnbli (ālmtūfi: 1051.), dqā'iq aūlī al-nhi lšrh al-mnthi al-m'rūf bšrh mnthi al-irādāt, 'ālm al-ktb, al-ṭb ‘̈t: al-' aūli, 1414. - 1993.

Nāṣr al-dīn abū s'îd 'bd al-lh bn 'mr bn mḥmd al-šīrāzì al-bị̣āwy (ālmtūfi: 685.) anwār al-tnzīl ū' asrār al-t' awyl, dār iḥīà' al-trāt al- 'rbī, bīrūt, al-ṭb '̈̈: al-’aūli - 1418 .

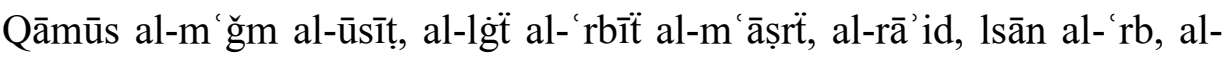
qāmūs al-mḥịṭ.

Šams al-dīn abū 'bd al-lh mḥmd bn mḥmd bn 'bd al-rḥmn al-ṭrāblsī almg̀rbī, al-m rūf bālḥtạa al-ruw'īnī al-mālkī (ālmtūfi: 954.), mwāhb al-

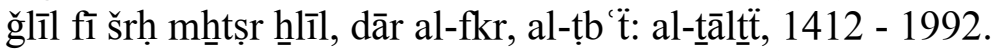




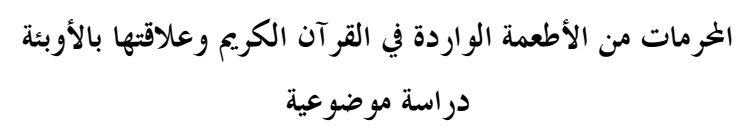

Šams al-dīn, mḥmd bn aḥmd al-ḥțīb al-šrbīnī al-šāf' ${ }^{\prime} \overline{1}$ (ālmtūfi: 977.), mġnī al-mḥtāğ, dār al-ktb al- 'lmīît, al-ṭb ‘̆t: al-'aūli, 1415. - 1994.

Șḥīḥ al-bh̄ārī brqm (2236) ūṣḥ̄ị mslm brqm (1581) mn ḥdīt ğābr, rḍ̂̄ allh 'nh.

Ș̣ịḥ mslm (4/1919-1922) (2473), ūhū 'nd abn ḥbān (16/77-82) (7133), $\overline{\mathrm{u}}^{\prime}$ aḥmd (5/174).

Taqī al-dīn abū al-'bās ạ̣md bn 'bd al-ḥlīm bn 'bd al-slām bn 'bd al-lh bn abī al-qāsm bn mḥmd abn tīmīì al-ḥrānī al-ḥnblī al-dmšqì, mğmū' al-

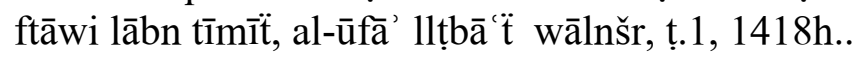

